\title{
The Theory and Practice of Boards: Evidence from the Field ${ }^{1}$
}

\author{
Miriam Schwartz-Ziv²
}

\begin{abstract}
We examine how the reality of the work conducted behind the closed doors of the boardroom relates to the projections made in economic models analyzing the work of boards: We analyze a unique set of data from a sample of real-world boardrooms - minutes of board meetings and board-committee meetings of eleven firms in which the Israeli government holds shares. The findings show that boards: usually discussed issues of supervisory nature (69\% of the cases), were usually given updates rather than an opportunity to make a decision (58\%), were virtually never presented with alternatives (1\%), rarely disagreed with the CEO $(2.5 \%)$, but from time to time did request to receive further information or an update (11\%). These findings do not support the economic models that predict that boards make decisions pertaining to the actual business, from a range of options; they do support the models that predict that, apart from replacing the CEO from time to time, the common ongoing work of boards is to monitor and assess the CEO.
\end{abstract}

\footnotetext{
1 We chose to mimic Graham and Harvey's (2001) title - "The Theory and Practice of Corporate Governance: Evidence from the Field," because the orientation of the current study is similar to theirs: they studied how capital structure practices compare, in reality, to the predictions made in economic models, and this study asks the same question about the work of boards.

2 The Hebrew University of Jerusal em, e-mail: miriam.schwartz@mail.huji.ac.il. I am grateful to Prof. Eugene Kandel and Prof. Michael Weisbach, the co-advisors of her doctoral dissertation, upon which this paper is based. I thank the executive and non-executive employees of the Government Compani es Authority of Israel, who allowed me both formally and practically, to conduct this res earch. I also thank the companies studied, which kindly provided me with private and sensitive data. In addition, I thank the following people who shared their thoughts and advice with us at different stages of the preparation of this paper: Amir Barnea, Alon Eizenberg, Ada Demb, Julian Franks, Ann Gillette, Ilan Guttman, Saul Lach, Avri Ravid, Arthur Raviv, Daniel Schwartz, Schraga Schwartz, Eytan Sheshinski, and Tammar Zilber. Last, I thank the Israeli Ministry of Science and Technology, and Hebrew University's School of Business Administration, for financial support.
} 


\section{Introduction}

In this paper we examine what happens behind the closed doors of the board-room, and whether that reality tallies with the projections made in economic models analyzing the work of boards. Little research has been conducted on the actual work of boards, which, in the words of Adams et al. (2009), has remained a "black box." Since board-meetings are private, earlier studies lacked direct access to what really goes on in the boardroom.

As Figure 1 demonstrates, the advantage of finance studies pertaining to boards is that they are able to make empirical examinations. However, these studies are confined to a limited scope of the work of boards. These studies examine how board-characteristics (such as the percentage of outside directors) or proxies reflecting the work of boards (such as CEO resignation) impact upon financial performance. In contrast, the advantage of the economic models modeling the work of boards is that they are able to examine specifically and exclusively how the actions board take impact board independence, their assumption being that board independence impacts positively upon firm performance. However, by definition, economic models are theoretical. In the case of boards, whose actions are as a rule unobservable, examining the predictions made by these models is generally impossible.

Hence, neither the economic nor the finance research approach is able to examine both empirically and exclusively the actual work conducted by boards. In contrast, we have fortunately been allowed to analyze a unique database of minutes of real-world boardrooms. Such a wealth of information about what happens at board and boardcommittee meetings is quite rare, as is evident from the scarcity of empirical documentation from recent years pertaining to what actually happens behind those doors. 
Using the content-analysis methodology, which is a method that enables the transformation of texts into a quantitative database, we analyze minutes of board and board-committee meetings of eleven companies in which the Israeli government holds shares - the extent of its holding ranging from $40 \%$ to $100 \%$ of the total. ${ }^{3}$ This methodology, which to our knowledge, has hitherto not been used to examine the work of boards, allows analyzing the direct outcomes of each issue discussed, or, using the terms of agency theory, analyzing the "unobservable" actions taken by the board-members.

First, we examine how what transpires in the "average" board meeting and boardcommittee meeting, relates to the models. One approach, adopted by studies such as Song and Thakor (2006), Adams and Ferreira (2007), and Harris and Raviv (2008), models boards as entities that make decisions pertaining to the actual business, from a range of options. Hence, this approach projects that a board is an active leader in directing the firm. A second approach, in contrast, which is adopted by Hermalin and Weisbach (1998), Graziano and Luporini (2003), and Dominguez-Martinez et al. (2008), predicts that boards only observe decisions made by their CEOs and the outcomes of those decisions. Based on these observations, the board may choose to retain or fire the CEO. Because CEOs are not fired very often, the upshot of this second approach is that, in practice, the common ongoing work of boards is to monitor and assess the CEO, rather than actively directing the business.

In the present study we do not find empirical support for the predictions made by studies taking the first approach. Namely, we find that $69 \%$ of the issues boards discussed were of supervisory nature ; that in $58 \%$ of cases, boards were given updates, rather than

3In Section 3.3 the representativeness the findings are discussed. 
an opportunity to make a decision, and that this was even more pronounced with regard to business issues; that boards partially or completely disagreed with the CEO in only $2.5 \%$ of the cases, and even more rarely concerning business issues; that in only one of every forty cases did the board not vote unanimously; that in more that $90 \%$ of the cases the board did not take an initiative; that in only one of every hundred cases was the board presented with more than one alternative. Taken together with the additional finding, that in $11 \%$ of the cases boards did request to receive further information or an update, these findings lend support to the second approach set out above, namely, that boards are supervisors and assessors of the CEO.

The paper is organized as follows: Section 2 describes business firms in which the Israeli government holds shares; Section 3 presents the data and methodology; Section 4 presents the findings; and Section 5 summarizes and concludes the study.

\section{Business Firms in which the Israeli Government Holds Shares}

As stated above, in this paper we examine the minutes of board and board-committee meetings of eleven business companies in which the Israeli government holds shares; we refer to them as GBCs (government business companies). This section presents the setting in which GBCs operate. For a more comprehensive description of GBCs see Supplement A. For a discussion of how our findings reflect other firms - specifically, the boards of listed firms, see the appendix at the end of the paper.

Thirty-four GBCs currently operate in Israel in various fields, including infrastructure, military technology, construction/housing, and services. All companies are overseen by the Government Companies Authority, which represents the government in its 
role as a shareholder. ${ }^{4}$ Table 1 presents key 2007 figures for the GBCs. As is evident, the size of these companies varies greatly: some companies employ only tens of employees, whereas others employ more than ten thousand. The annual income of the smaller GBCs is just a few million USD, whereas the comparable figure for the larger firms is one to four billion USD. The latter firms are very large, according to Israeli standards. ${ }^{5}$

Israel's 1999 "Corporation Law" and 1975 "Government Companies Law" which both apply to the firms examined, detail the duties incumbent upon their boards. Both laws stress that the board must determine the company's policy. In addition, both laws stress that the board must monitor the CEO. Concerning "business companies", which are the firms examined in this study, the Government Companies Law explicitly requires that "the firm operate according to business considerations just as firms with no government shareholder do". 6

Board-members of GBCs are elected by an exogenous factor - the government's ministers, and in practice, their re-nomination does not depend on their/the firm's performance. For a detailed discussion on this issue, including an empirical demonstration of this argument see Supplement A. The Government Companies Law requires that in companies in which the government holds more than half the votes in the general stockholders' meetings, board-members must be at least twenty-five years old, be residents of Israel, and either have degrees in business, economics, law, accounting, engineering, public service, or any other field relevant to the firm, or have at least five years of relevant

${ }^{4}$ Miriam Schwartz-Ziv worked in the Gov ernment Companies Authority from 2006 until 2010.

5 The median income of 662 companies that were traded at the Tel-Aviv Stock Exchange in 2007, and for which data is available, was 36 million USD; the average figure was 265 million USD. In 2007, only six companies traded on the TASE had income that exceeded that of the Israel El ectricity Company, the largest government com pany in Israel.

${ }^{6}$ All translations from Hebrew in this paper are by Miriam Schwartz-Ziv. 
experience or experience in a senior management position. The requirements regarding the chairman are even stricter.

The only compensation given to board-members is a fixed compensation for each board or board-committee meeting they attend. This compensation amounts to \$185 $\$ 350$, depending upon the size of the company.7 Although this financial compensation is not high, there are always candidates interested in nomination to boards of GBCs, since such positions provide, inter alia, status and the expansion and strengthening of one's professional network, and also enable the development of an expertise in demand in the better-paying private sector. Fama and Jensen (1983), Lorsh and MacIver (1989), and Yermack (2004) further elaborate on the advantages that accrue to board-members.

\section{Data and Methodology}

Minutes of board-meetings and board-committee meetings were coded (as shall be described hereafter) for a period of one year for each of the eleven firms examined. The calendar year studied was during the period 2007-2009 - for eight of the firms, calendar 2008. Nine of the eleven companies examined provided minutes of both board meetings and board-committees; the other two supplied only the former. These data aggregate to 402 meetings of the boards or their committees (155 and 247, respectively), in which according to my tabulation - 2459 decisions were made or updates were given (1422 and 1037, respectively).

\footnotetext{
7 In small and medium companies, the chairman is not employed on a full-time basis, and he receives compensation only on a basis of meeting he actually attended, compensation which is approximately $20 \%$ higher than that paid to board members. In large companies, the chairman is employed on a full-time basis, and accordingly receives (only) a monthly salary. State employees or company employees receive no additional remuneration for serving as board-members.
} 
Due to confidentiality commitments made to the firms, which kindly provided copies of their minutes, we do not mention which specific firms were examined. ${ }^{8}$ However, I may state that all firms examined are included in Table 1, that they are of different sizes, as measured by annual income, with a tendency toward the larger GBCs; that they reflect quite representatively the fields in which Israeli government firms operate; and that of the eleven firms examined, nine were completely, or virtually completely, owned by the Israeli government, the other two only partially (less than $50 \%$ of the shares were held by the government).

An important point which must be noted is that we do not analyze what occurs between the CEO and the board-members outside the boardroom. Undoubtedly, important occurrences take place outside the boardroom, but unless they are mentioned in the minutes, it is not possible to be aware of them. Nevertheless, although there are discussions and interactions outside the boardroom, the bulk of board-activity - including the decisionmaking process - takes place in the boardroom, so the analysis that shall be presented is valuable. In addition, we do not judge whether the actions taken by boards were positive or negative.

The data was coded according to content-analysis methodology (Krippendorff, 2004; Lieblich et al., 1998) which enables the transformation of qualitative data into quantitative figures. The essentials of the coding guidelines are as follows (for a complete presentation, see Supplement C):

i. General information. For each update or decision, we recorded the name of the company, date of meeting, number of pages and type of meeting (board/

\footnotetext{
${ }^{8}$ All firms examined are included in Table 1.
} 
committee), and whether the issue was merely presented as an update or, alternatively, culminated in a decision made by the board.

ii. Topic-subjects. Each topic discussed or decision made in a board meeting or boardcommittee meeting, was coded under one of the following twenty-three topicsubjects (listed alphabetically): appointing/ firing an executive, appointment of members, approving minutes of past meetings, audit, budget, business issue, business project, choosing a chairman for the meeting, contracting/purchases, cross-firm issues, financial reports, formal issues, investment/finance, legal, ongoing general issues, organizational change, personnel and compensation, ratification of audit committee, ratification of financial committee, ratification of human resources committee, ratification of operational committee, regulation and government, strategic issues. Detailed definitions for each category are provided in Supplement C.

iii. Aggregate topic-subjects. Each of the twenty-three topic-subjects listed in the previous paragraph was assigned to one of five aggregate topic-subjects. Thus, for example, the aggregate topic-subject "business issue" includes the following topicsubjects: business issues, business projects, cross-firm issues, ongoing general issues, ratification of operational committee, regulation and government, and strategic issues. For details, see Tables 3 and 5-8.

iv. Decision in line with CEO. For each decision made by the board, the decision was coded as either in line, partially in line, or not in line with the CEO's/management's proposal. 
v. Further updates. Cases in which the board requested to receive further information or an update on the subject discussed.

vi. Taking an initiative. When a board actively did something that was meant to improve the company, according to its own understanding, this was coded either as a "minor initiative" or as a "major initiative." "Minor initiative" indicates that the board slightly modified the original proposal. For example: The board approved a lease it was asked to approve, yet decided to introduce a few revisions of details. "Major initiative", indicates that the board took an active part in defining the steps/actions that should be taken. For example: A board delved into an issue presented to it, or one it actively requested be discussed, discussed the issue quite thoroughly, and finally, formulated and adopted a new alternative policy.

vii. Presentation of alternatives. Cases in which the board was presented with at least two alternatives.

viii. Dissension. Cases in which a decision was made, and one or more of the boardmembers did not vote as the others (either opposing them or abstaining).

ix. Supervision. All topic-subjects were divided according to whether they were of supervisory nature or not. Supervisory topic-subjects were defined as: appointment of members, approving minutes of earlier meetings, audit, choosing a chairman for the meeting, contracting/purchases, financial reports, formal issues, legal, personnel and benefits, ratification of audit committee, ratification of human resources committee, ratification of operational committee, ratification of financial committee, 
and regulation and government. ${ }^{9}$ Non-supervisory topic-subjects were defined as: appointing/firing an executive, budget, business issue, business project, cross-firm issues, investment/finance, ongoing general issues, organizational change, and strategic issues.

x. Consistency. All coding was done by the author. ${ }^{10}$ To assure consistent standards, she reviewed all coding at least twice.

In order to address certain issues, the database assembled is analyzed via OLS regressions, as shall be detailed with regard to those specific issues.

\section{Findings and their Relation to Extant Theory}

In this chapter the findings are presented. For each issue examined, relevant literature is presented, which includes both empirical and theoretical studies. In Supplement D we present real situations encountered in the minutes which illustrate the findings, and suggest that the situations encountered by the boards we examined may easily be encountered by other boards as well.

The analysis in this chapter is divided into two parts. In the first part the different roles of the board are analyzed. In this part we examine how and to what extent the board carries out its supervisory role, as well as the involvement of boards in the actual business of the firm, including whether they have, in practice, the opportunity to choose among options. The second part focuses upon board-dynamics. Here we examine the extent to

9 For example, if a board approved a financial report, it was classified under the category of supervision because the board's role with regard to these reports is mainly verifying that they are properly conducted.

10 This was due to the fact that the minutes are in Hebrew and, due to confidentiality, were made available only to the author and her doctoral advisors. 
which boards vote in line or vote only partially in line with the CEO's proposal; whether lack of unanimity ("dissension") is prevalent; and to what extent boards take the initiative.

\subsection{The Board's Roles}

Boards are considered to have two major roles: supervising the CEO and the management (as emphasized in the Sarbanes-Oxley Act), and being actively involved in the actual business of the firm (as emphasized for example in the Delaware General Corporate Law $^{11}$ ). In this section these two roles are examined.

\subsubsection{Supervising}

Literature. On the empirical level, Mace (1971), who conducted interviews with boardmembers and managers, stresses that boards serve as some sort of discipline for the CEO and the management. He found that the mere fact that a CEO must review his or her business before board meetings, and report to his peers, is beneficial. Lorsh and Maclver (1989) and Carter and Lorsh (2003) second this conclusion.

The economic models developed in the last decade, which are rooted in agency theory (Holmstrong, 1979; Jensen and Meckling, 1976; Fama, 1980; Tirole, 1986), treat monitoring, as agency theory does, only as an "independent" variable that along with other variables, determines a "dependent" outcome. Thus, one strand of economic models examines how the intensity with which a board monitors impacts upon the project it selects or the scale of investments it chooses (Song and Thakor, 2006; Adams and Ferreira, 2007; Harris and Raviv, 2008).

\footnotetext{
${ }^{11}$ As its paragraph 141(a) states: "The business and affairs of every corporation ... shall be managed by or under the direction of a board of directors".
} 
A second strand of models examines how the intensity with which a board monitors the CEO impacts upon the board's decision to retain or fire him (Hermalin and Weisbach, 1998; Almazan and Suarez, 2003; Graziano and Luporini, 2003; Hermalin, 2005; Dominguez-Martinez et al., 2008; Laux, 2008). Specifically Hermalin and Weisbach (1998), Graziano and Luporini (2003), and Dominguez-Martinez et al. (2008) all emphasize the direct causal link between the outcomes of the business decisions made by the CEO and the decision of the board to retain or eject the CEO.

In both strands of models, monitoring is not studied as an outcome but only insofar as it impacts upon the selection of a project or the CEO's fate. However, because CEOs are not fired very often - terms of CEO's average around 6 years ${ }^{12}$ and many willingly resign - the second strand of models, which deals with the CEO's fate, predict that, generally, the work conducted by boards is somewhat circular: The CEO proposes a project, the board observes the earnings derived from it, uses this information to decide whether to retain or eject the CEO, and as is evident in practice, in most cases the board decides to retain the CEO. That is, the board's work consists of supervising the CEO and assessing his performance.

Evidence from this study. Monitoring is a major part of the work of boards. Monitoring comes in several forms, as shall now be briefly detailed. Boards are provided with updates so as to enable them to monitor and supervise the work of the CEO and the management. Panel 2 of Table 3 presents a break-down of the number of decisions made and updates supplied on a topic-subject level. The data in this panel demonstrate that receiving updates was more common than making decisions: the boards examined

${ }^{12}$ According to Favaro et al. (2010), “CEO succession among the world's top 2,500 public companies" equals 6.3 years. 
received, aggregately, 1422 updates, while they made only 1037 decisions (i.e., 58\% versus $42 \%$ respectively). The relative high frequency of updates allowed boards to stay abreast of the firm's affairs, i.e., to monitor and supervise.

Apart from that tabulation, each of the topic-subjects is defined as one of supervisory nature or not. ${ }^{13}$ As Table 4 indicates, $69 \%$ of the issues discussed by the boards were in its supervisory role. These findings, too, demonstrate the strong emphasis boards put on supervision.

In addition, we examine a variable that documents whether requests were made to receive further information or an update, since this variable is a good indicator of the scope and intensity of a board's monitoring of the CEO. As detailed in Panel 2 of Table 5, which aggregates all cases examined, on the average boards requested to receive further information or an update in $11 \%$ of the cases.

Turning now to data at the firm level, Table 2 presents summary statistics for the main variables that document the opportunities boards received and the actions they took at board meetings and board-committee meetings of the eleven firms examined. As presented in Table 2, the average percentage of cases in which boards of a given firm requested to receive further information or an update had a rather large spread, ranging from $1 \%$ to $21 \%$ (average - $8 \%$, S.D. - 0.067). Yet, it should be noted that not all information requested by board-members was necessarily provided to them. It is not

\footnotetext{
13 As defined in Section $4 \mathrm{j}$, all topic-subjects were divided according to whether they were of supervisory nature or not. Supervisory topic-subjects were defined as: appointment of members, approving minutes of earlier meeting, audit, choosing a chairman for the meeting, contracting/purchas es, financial reports, formal issues, legal, personnel and benefits, ratification of audit committee, ratification of human resources committee, ratification of operational committee, ratification of financial committee, and regulation and government. Non-supervisory topic-subjects were defined as: appointing/firing an executive, budget, business issue, business project, cross-firm issues, investment/fi nance, ongoing general issues, organization al change, and s trategic issues.
} 
possible to examine this issue, since such information is often provided via means of communication outside the boardroom.

Taken together, these findings stress that boards devote a large proportion of their work to supervision, which comes in the form of the frequent updates boards receive, the issues of supervisory nature that are discussed, and the follow-up boards conduct by requesting to receive further information or an update.

Comparison of the findings to extant literature. This study demonstrates that the routine and humdrum work of supervision conducted by boards, which is burgeoning in the SOX era, is the dominant part of their work. The findings stress that most of the work of boards consists of supervision, possibly even more than is acknowledged. Perhaps, therefore, monitoring might even be regarded as the outcome of the work of boards, rather than an "independent" factor that impacts upon the "dependent" outcomes of boards' work, which is how it is viewed in the economic models analyzing the work of boards. These findings thus provide support for models that predict that, in fact, the board's major ongoing role is to monitor the CEO (Hermalin and Weisbach, 1998; Gr aziano and Luporini, 2003; Dominguez-Martinez et al., 2008).

\subsubsection{Involvement in the Actual Business}

Literature. Empirical qualitative studies tend to focus on the role of the board in such pivotal fields as the formulation of the firm's strategy. Thus, for example, Demb and Neubauer (1992), Judge and Zeithaml (1992), and Stiles (2001) all explore the contribution of a board to a firm's strategy. They all find, one way or another, that although boards are involved in the firm's strategy, which in the nature of things includes business issues, their 
ability to actively shape the strategy/business seems to be limited. However, these studies devote little or no attention to the "average" or standard board meeting.

In contrast to the empirical studies, the economic models that examine the work conducted by boards seem to envision a board that is focused on the actual business/strategy of the firm. Thus, Adams and Ferreira (2007) and Dominguez-Martinez et al. (2008) present a model in which the board is presented with "projects". DominguezMartinez et al. (2008) define these "projects" as "anything that is meant to have a substantial impact on the company, for example, restructuring, diversification, [or] acquisition". Similarly, in the scenario posited by Song and Thakor (2006) "project ideas" are presented, in Graziano and Luporini (2003) an investment is undertaken, and in Harris and Raviv (2008) the optimal scale of an investment is chosen.

Description of analysis conducted. We examine whether boards are significantly less likely to make a decision with regard to business-related issues as opposed to receiving updates about these issues. This analysis is conducted via OLS (ordinary least squares) regressions presented in Table 8 . The data analyzed are the 2459 cases in which the boards of the eleven firms examined received an update or made a decision at a board meeting or a board-committee meeting. The dependent variable examined is a binary variable which equals one in cases in which the board made a decision, as opposed to receiving an update.

The independent variables included in the regressions are (in the order listed in Table 8) dummy variables documenting: whether a business issue was discussed, whether the discussion was held at a board-committee as opposed to a board meeting, whether the firm was in an interregnum (between CEOs), log income of firm, number of board- 
members, and log of the total number of meetings (of both the board and its committees). All variables are defined in List 1.

Following a Hausman test, conducted but not reported, as in Adams and Ferreira (2010) the regression was conducted twice: the first regression (Regression 1 in Table 8) does not control for fixed effects across firms, while the second (Regression 2 in Table 8) does. The latter regression allows the inclusion of three variables for which, by definition, perfect multilinearity exists between them and firm dummies: log income $\mathrm{T}-1$, number of board-members, and log number of meetings. ${ }^{14}$

Evidence from this study. As is evident from Panel 1 of Table 3, the boards examined devoted only a limited portion of their attention to discussions pertaining to the actual business of the firm, and these were not the dominant issues discussed: Analysis on the aggregate topic-subject level shows that only $24 \%$ of the discussions pertained to business issues, and only $1 \%$ pertained to issues of strategy. True, in defense of boards it may be argued that some of the business projects they discussed may be regarded as strategic projects. Nevertheless, the findings stress that the boards examined rarely had formal and structured discussions of the firm's strategy in general, or even of the firm's strategy regarding a specific major issue/field.

As mentioned, Panel 2 of Table 3 demonstrates that boards usually (58\% of the cases) receive updates, rather than make decisions ( $42 \%$ of the cases). However, this situation is even more pronounced regarding business-related issues: As Panel 2 of Table 3 indicates, on the aggregate topic-subject level, in $67 \%$ of the cases in which boards

\footnotetext{
14 Because the dependent variables documenting the actions board-members take are binary, there arises the fundamental question regarding the preferred method - binary logistic or linear (Wooldridge, 2009 and Greene, 2008). To assure robustness, the data were analyzed using both methods. The results turned out quite similar, hence only thos e of the linear regressions are presented.
} 
discussed business issues they were provided with updates; only in the remaining $33 \%$ did they make decisions on these issues.

Finally, Table 8, which presented the analysis described above in this section, examines the likelihood that the board will receive an update, as opposed to it having an opportunity to make a decision, with regard to business-related issues. As described above, a dummy independent variable is included which controls for whether a businessrelated issue was discussed. The results indicate that boards are significantly more likely to receive an update, as opposed to making a decision with regard to business-related issues.

Comparison of the findings to extant literature. The findings are consistent with prior empirical qualitative studies that find that boards are involved only to a limited extent in the strategy/business-related issues of the firm. However, this study presents evidence on the tactics CEOs use to maintain this situation: they provide the board with updates concerning business-related issues, but abstain from requesting that the board make decisions about these issues.

With regard to the economic models, the findings do not provide support for models that predict that boards focus on the actual business of the firm (Song and Thakor, 2006; Adams and Ferreira, 2007; and Harris and Raviv, 2008).

\subsubsection{Choosing from among Options}

Literature. Song and Thakor (2006) define the role of the board as responsible for screening projects among the ideas proposed by the CEO. They conclude that after the board has been presented with several alternative projects, the board will choose the 
optimal projects (a choice which in their analysis may be impeded by the career concerns of those involved in the decision). So too Adams and Ferreira (2007) depict a board-room in which the board chooses an optimal project out of two or more alternatives. The present study asks the basic question: Are boards indeed presented with alternatives?

Evidence from this study. As Table 2 presents, at the firm level, in only $1 \%$ of the cases in which decisions were made was the board presented with more than one option. the average percentage of cases in which boards were presented with more than one alternative ranged from $0 \%-4.55 \%$. Accordingly, almost always, boards could only accept or reject a single proposal.

Comparison of the findings to extant literature. The findings do not support the prediction made in Song and Thakor (2006) and assumed by Adams and Ferreira (2007), that boards will get an opportunity to choose an optimal project from several proposed projects.

\subsection{Board-dynamics}

This section examines board-dynamics and actions the board-members choose to take.

\subsubsection{Disagreement between the Board and the CEO}

Literature. Mace (1971) finds that boards do not ask discerning questions, or in the terms of Patton and Baker (1987), that they "refuse to rock the boat". Similarly, Lipton and Lorsch (1992) find that in practice, board-members try to avoid confrontation with the CEO.

In contrast, economic models analyzing the work of boards examine how boards select projects that may well not be in line with the CEO's suggestion. Thus, for example, 
Adams and Ferreira (2007) present a model that focuses on the built-in tension between the board's two major roles: advising the CEO but, at the same time also monitoring him. In their model, the board must choose an optimal project. This project must maximize shareholders' wealth, and they explicitly expect it to be, generally, different than the one the CEO would choose. They consider monitoring as successful if the board can impose its' preferred project.

Similarly, Harris and Raviv (2008), who analyze the tradeoffs between having an inside- versus an outside-dominated board, predict that the board will in practice determine the optimal scale of the investment for a project. In their analysis, in mo st cases the information provided by outsiders engenders a decision that the scale of the project differ from that of the original proposal. Hence, both Adams and Ferreira (2007) and Harris and Raviv (2008) predict that the board will, in practice, make decisions that are not in line with the original proposals made by the CEO.

In contrast, Warther (1998), whose model of the work of boards also takes in account the costly outcomes that dissension may have for board-members who deviate from their colleagues' vote, predicts that in most cases the board will vote in favor of management. A similar concept is suggested by Hermalin and Weisbach (1998), who predict that the board's discretion pertains to the selection and ejection of the CEO. Similarly, both Graziano and Luporini (2003) and Dominguez-Martinez et al. (2008) model a board which does not choose the optimal project; rather, it chooses between retaining and firing the CEO. Since, as mentioned, CEOs are not fired on a monthly or even annual basis, these models support the prediction that, in practice, in most cases the board will vote in line with the CEO. Moreover, the Dominguez-Martinez et al. (2008) model explicitly 
stresses that the board will not limit the CEO's actions, since allowing the CEO free rein will enable the board to acquire a signal as to whether the CEO is a good or a bad type.

Evidence from this study. Boards almost always approved what they were asked to approve. According to Table 6, on the average in only $0.9 \%$ of the cases did the boards vote against the CEO's/management's view, and in only an additional $1.5 \%$ of the cases was their vote only partially in line with the CEO's/management's view; thus, only in one of forty cases did the board refuse, completely or partially, to ratify the CEO's proposal. As Table 2 indicates, on the firm level the disagreement rate of all cases examined (i.e., the percentage of cases in which boards either did not vote in line with the CEO's proposal or voted only partially in line with it) ranged from $0 \%-7.9 \%$, depending on the firm (average 2.5\%, S.D. 0.022).

Interestingly, as Table 6 indicates, with regard to the aggregate topic-subject "business issues" the percentage of cases in which boards totally or partially rejected the CEO's proposal with regard to business issues is only $1 \%$ - even lower than the abovementioned average for all cases (2.5\%).

Comparison of the findings to extant literature. These findings do not support the predictions, made in Song and Thakor (2006), Adams and Ferreira (2007), and Harris and Raviv (2008), that boards will, in practice, vote completely or partially against the CEO's proposal at a notable rate. ${ }^{15}$ Rather, they support Warther's (1998) prediction that boards will usually vote in favor of management's proposal, which corresponds to the

\footnotetext{
15 Adams and Ferreira (2007 - p. 6) note that their model pertains to "non-routine" projects. Accordingly, one might suppose that their conclusion, that boards will not support the CEO's proposals, is valid for such projects. However, since the present study shows that cases of non -approval or only partial approval are very rare $(2.5 \%$ of the cases examined), that would imply that their model pertains only to a very limited portion of the work of boards.
} 
prediction, posited by Hermalin and Weisbach (1998), Graziano and Luporini (2003) and Dominguez-Martinez et al. (2008), that the CEO will be the one making decisions in practice. Hence, the findings presented may be interpreted as indicating that once the board has chosen a CEO - and that is indeed a major decision entrusted to the board - the CEO will be the one calling the shots.

\subsubsection{Dissension among Board-members}

Literature. Merchant and Pick (2010), who conduct an empirical analysis, stress that dissension may be beneficial, since it allows critical thinking, yet, on many boards it is regarded as either superfluous or harmful. Leblanc and Gillies (2005) stress that after a serious discussion is held it is desirable that a board reach a consensus and vote unanimously.

Warther (1998) presents a model that addresses the extent to which dissension exists within a board. He models the effectiveness of the board in disciplining management, while taking into account the power of the latter to select and eject boardmembers. He stresses that a board-member who acquires a negative signal about the CEO's managerial ability may be ejected by the board if his view ends up being a minority opinion. For this reason, Warther's model predicts that board-members will usually choose to operate unanimously and calmly, and that conflicts will arise only occasionally. Accordingly, the model predicts that votes will usually be unanimous (i.e., none of the board-members will oppose the others or abstain). The other economic models mentioned in this study model the board as an entity with a single opinion, and do not directly address differences of opinions between the board-members. 
Evidence from this study. As Panel 1 of Table 6 shows, in only $2.5 \%$ of the 1422 cases examined in which decisions were made by the board, did the boards vote nonunanimously, which this study terms "dissension". As Table 2 indicates, on the firm level dissension rates varied rather significantly - from 0\%-18.8\%, (average - 3.27\%, S.D. 0.0536). Figure 2 compares the dissension rates documented, broken down according to the number of board-members in attendance. This figure also presents the dissension rates expected if the votes where random, i.e., $\mathrm{P}$ (dissension will transpire |votes are random) $=0.5^{-1}, n$ being the number of board-members in attendance. As Figure 2 indicates, dissension rates do grow as the number of board members grows, yet dissension rates do not approach the rates expected if voting were random.

The low rates of dissension demonstrate that even when management is not involved in the selection-ejection mechanism of the board-members, which is the case in the firms examined as explained in Chapter 2, board-members prefer not to dissent from their peers' opinions. Rather, they prefer to work in harmony.

Comparison of the findings to extant literature. The findings strongly support Warther's (1998) prediction that boards will usually vote unanimously. In addition, the findings support modeling the board as an entity with a single opinion, as is the case in the other models we have surveyed.

\subsubsection{Taking Initiative}

Literature. Responding to a questionnaire distributed by Lorsch and MacIver (1989, p. 72), directors were requested to describe how valuable they considered their board meeting contribution, on a scale of 1 ("a great deal") to 5 ("very little"). $63 \%$ of the 
respondents chose either $1(12.3 \%)$ or 2 (49.6\%). Yet, when the respondents were asked how much influence they believe the CEO has on the majority of board issues, the mean response was 1.6 - indicating the respondents viewed the CEO as having great power in the board-room. In other words, directors view themselves as secondary in their firm's hierarchy of power, but nevertheless believe their role is real. This jibes with the findings of McNulty and Pettigrew (1999), Stiles (2001), and Leblanc and Gillies (2005), that directors are involved in setting strategy but rarely initiate and formulate strategic plans.

In the economic models analyzing the work of boards (Fama and Jensen, 1983; Song and Thakor, 2006; Adams and Ferreira, 2007; Harris and Raviv, 2008) boards are not modeled as entities that regularly propose projects, or actively suggest alternatives. Instead, as mentioned, Song and Thakor (2006) and Adams and Ferreira (2007) predict that boards will choose, rather than propose, the optimal project, while Harris and Raviv (2008) predict that they will choose, rather than propose, the optimal scale of a project. These models agree that the board-members' active contribution is expressed in choices made by the board from options proposed to them.

Evidence from this study. To study the tendency of boards to make their own active contribution, we examine how often a minor or a major initiative was taken by the board. As defined in detail in Section 3vi, a "minor initiative" refers to a situation in which the board slightly modified the CEO's original proposal, while a "major initiative" was defined as one in which the board took an active part in defining the steps/actions that should be taken.

Table 7 presents the number of cases in which boards took a minor or a major initiative with regard to each of the topic-subjects. The results demonstrate that the boards 
examined took a minor or a major initiative with regard to $5.1 \%$ and $4.2 \%$ of the topicsubjects discussed, respectively. In the other $90.7 \%$ cases, boards did not take either of these two actions. As Table 2 reports, on firm level boards took a minor initiative in $0 \%$ $10.9 \%$ of the cases (average: $4.7 \%$, S.D. 0.032 ), and a major initiative in $0 \%-7.7 \%$ of the cases (average: $3.4 \%$, S.D. 0.024).

Interestingly, as presented in Table 7, boards tended to take a minor or a major initiative especially with regard to the topic-subjects appointing/firing an executive, audit, and financial reports. All these are issues which, by law, the boards were specifically required to manage, or for which the law made them responsible.

Comparison of the findings to extant literature. The findings, which stress that boards make an active contribution only with regard to a rather limited scope and proportion of the issues discussed, are in line with both empirical and theoretical studies. The findings provide support for how boards are modeled in economic models (Song and Thakor, 2006; Adams and Ferreira, 2007; Harris and Raviv, 2008): at most they chose a proposal from among more than one offered by the CEO, rather than initiating one.

\section{Summary and Conclusions}

In this paper we examine how the generally "unobserved" actions taken by boards relate to the predictions made in economic models. The Summary-table compares the findings of this study to the predictions made in the extant economic models analyzing the work of boards. 
Summary-table

\section{Boards: Theory in Comparison to Empirical Findings}

\begin{tabular}{l} 
Theory \\
\hline The Different Roles of the Board \\
Monitoring is the most common task \\
performed by boards (implied by Hermalin \\
and Weisbach, 1998; Graziano and Luporini, \\
2003; Dominguez-Martinez et al., 2008).
\end{tabular}

Boards are focused on the actual business of the firm (Song and Thakor, 2006; Adams and Ferreira, 2007; Harris and Raviv, 2008)

Boards are presented with alternatives (Song and Thakor, 2006; Adams and Ferreira, 2007).

\section{Board-Dynamics}

Boards will usually vote in favor of management's proposal (Warther, 1998; implied by Graziano and Luporini, 2003 and Dominguez-Martinez et al., 2008).

Board will, in practice, make decisions that are not in line with the CEO's proposal (Adams and Ferreira, 2007; Harris and Raviv, 2008).

Votes will usually be unanimous (Warther, 1998).

Boards are not modeled as entities that regularly propose projects or actively suggest alternatives (all models mentioned in this paper).
Evidence from this study

$\checkmark$ A major part of the work of boards consists of monitoring - accomplished via the frequent updates boards receive, the issues of supervisory nature that are discussed, and the follow-ups boards conduct.

$x$ Business issues do not dominate the discussions; concerning business-related issues boards are significantly more likely to receive updates than to make a decision.

$x$ Boards were presented with more than one alternative no more than once in every 100 cases.

$\checkmark$ Boards did not vote in line with the CEO's proposal, or voted only partially in line with it, in only $2.5 \%$ of the cases.

$x$ As explained above.

\author{
$\checkmark$ In $97.5 \%$ of the cases, the boards voted \\ unanimously. \\ $\checkmark$ The boards examined took a minor or a major \\ initiative only from time to time: in $5.1 \%$ and in \\ $4.2 \%$ of the topic-subjects discussed, \\ respectively.
}


As the Summary-table indicates, the findings pose a question-mark regarding the predictions made in models analyzing the work of boards. Song and Thakor (2006) and Adams and Ferreira (2007) predict that boards decide which projects the firm should carry out and which not, or, in the terms of Harris and Raviv (2008), they choose the optimal scale of the project. However, the empirical findings of this study show that, de facto, boards do not call the shots. Rather, usually they get updates rather than make decisions, they are not presented with alternatives, and they agree with the CEO. These findings support the models of Hermalin and Weisbach (1998), Graziano and Luporini (2003), and DominguezMartinez et al. (2008), which predict that, in practice, the board's regular work consists of observing the business decisions made by the CEO rather than making such decisions itself.

To conclude, we may refer to the expectation formulated by the Delaware General Corporate Law (paragraph 141(a)), which is representative of such laws in most modern jurisdictions including Israel. It states that: "The business and affairs of every corporation ... shall be managed by or under the direction of a board of directors". As we have seen in this paper, many economic models analyzing the work of boards mirror this notion. However, as the empirical examination conducted in this study demonstrates, the reality of the work of boards is not always precisely in line with the ideal vision of legislators and the predictions of one set of economic models. Recognition of the ways boards are able to carry out their role, in practice, may well allow scholars, and also legislators, practitioners and stakeholders, to identify what is possible to expect from boards and how they may best contribute to the workings and success of firms. 


\section{Figure 1}

\section{The Work of Boards in Finance and Economic Studies}

This figure pres ents the scope within which boards are examined in economic models modeling the work of boards, and in the finance literature. As the right square in the figure indicates, the advantage of finance studies is that they are able to examine em pirically the work of boards. However, their analysis is confined to a limited scope of the work of boards - usually to the link between board-characteristics (e.g., size of board) or available proxi es reflecting the work of boards (e.g., board m eeting frequency), on the one hand, and firm performance, on the other. In contrast, as the left square indicates, economic models are able to focus exclusively on the actual work of boards, i.e., the actions boards take, and how these actions affect board independence, where the latter is assumed to be positively correlated with firm performance. However, by definition, economic models are theoretical, and in the case of boards - where most of their work is unobservable - significant portions of these economic models are not empirically verifiable. As indicated by the round arrows on the left side of this figure, in contrast to the extant studies, our access to data documenting the unobserved actions taken by boards has allowed us to examine empirically the work of boards, and how it rel ates to the predictions made in econo mic models.

This Empirical Study (round arrows)
Theoretical Economic Models

(left square)
Empirical Finance Models

(right square)

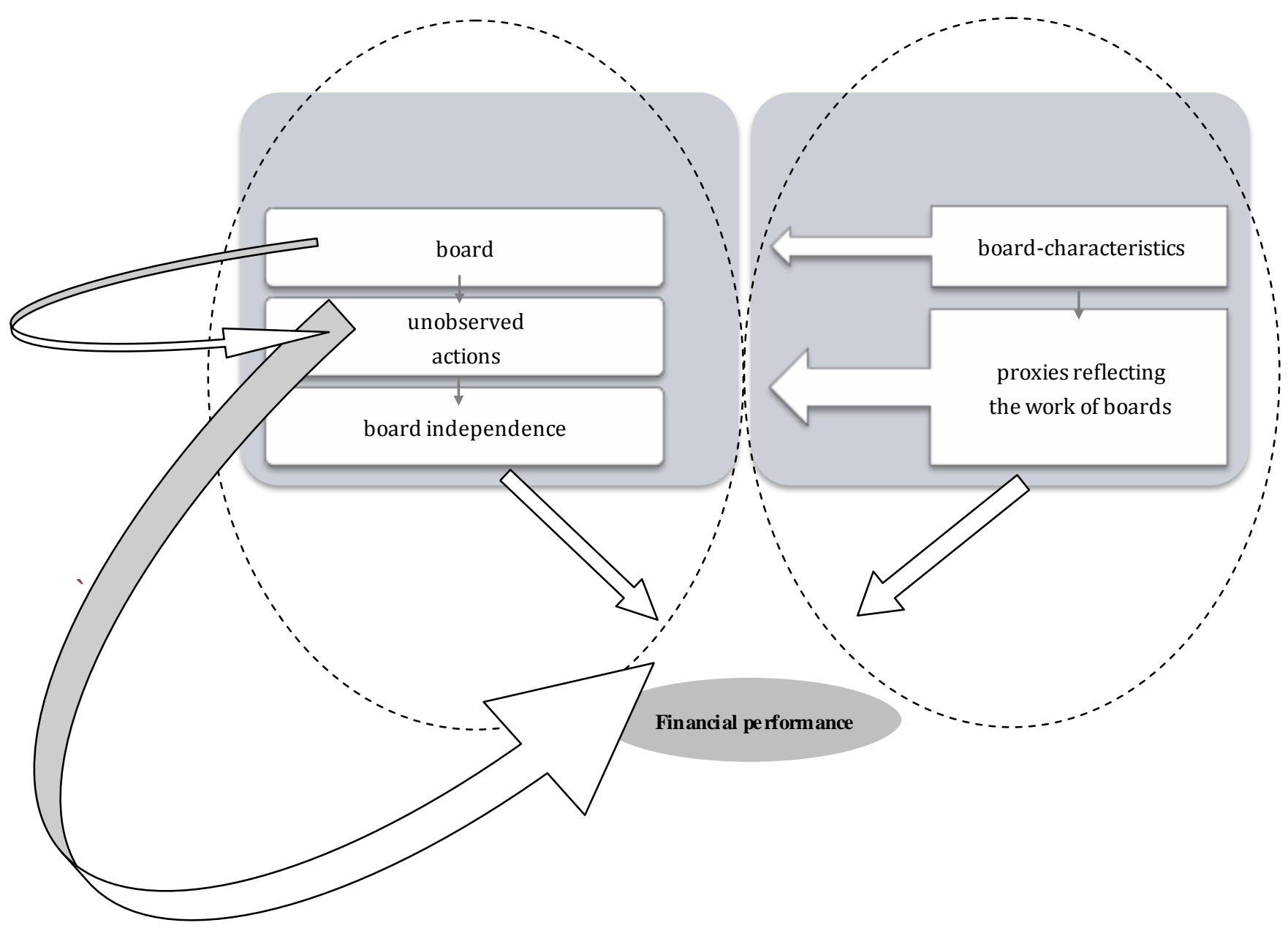




\section{Figure 2}

\section{Dissension within the Board}

The black line presents the actual dissension rates exhibited in the 1422 cas es in which the boards of the eleven GBCs examined made a decision at a board meeting or a board-committee meeting, broken down on the X-axis according to the actual number of board-members in attendance. Dissension is defined as a case in which one or more of the board-members did not vote as the others (either opposing them or abstaining). The grey line represents the dissension rate expected if the votes were random, i.e., P(dissension will transpire ( votes are random) $=0.5^{n-1}, n$ being the number of board-members in attendance.

This graph demonstrates that dissension becomes more frequent as the number of board members grows, but does not approach the rates expected if it were random.

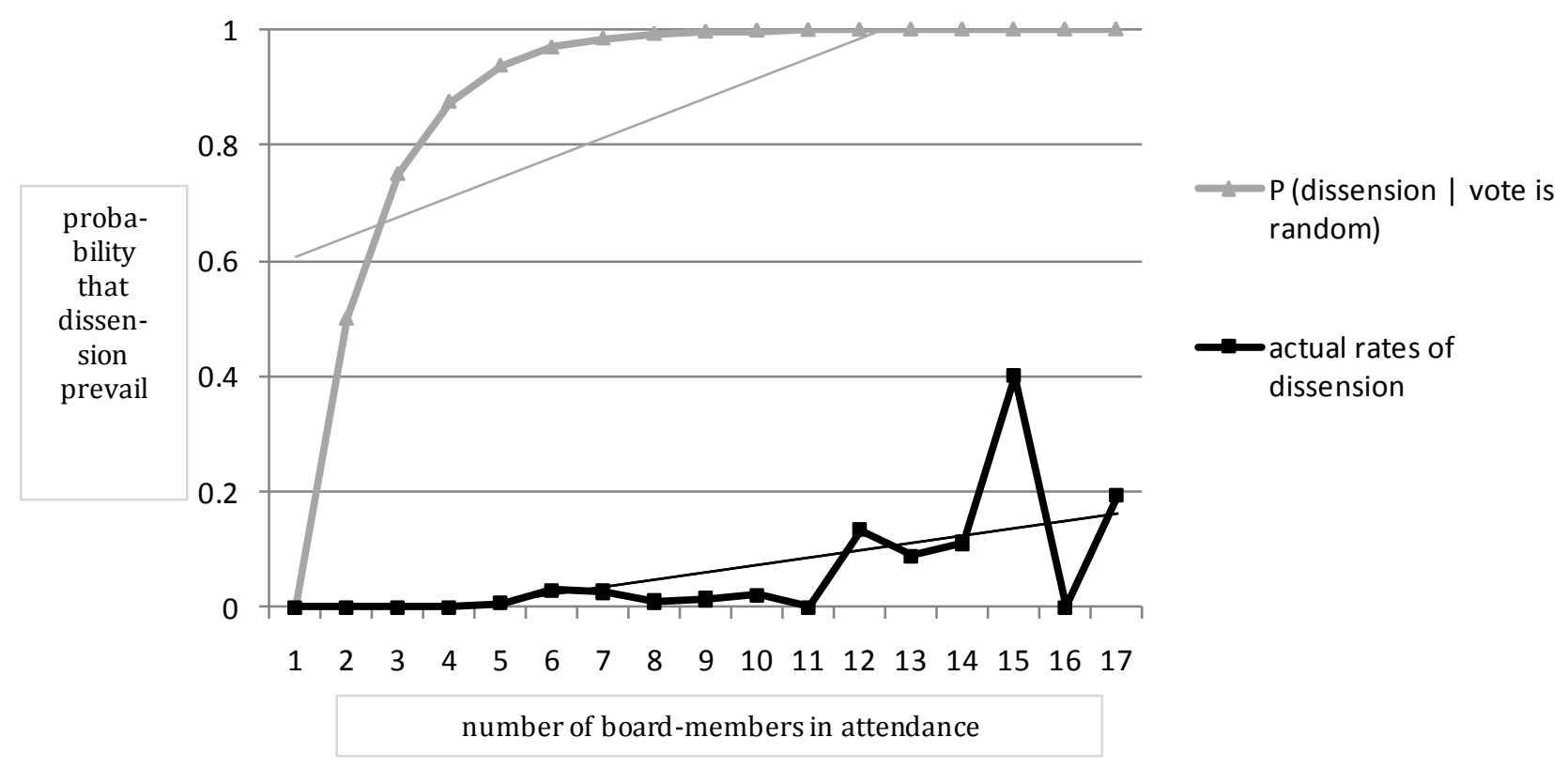


Table 1

Business Companies in which the Israeli Government Holds Shares (GBCs)

This table pres ents 2007 figures for all firms engaged in business activities in which the Is raeli government held shares that year. Since the statistical analysis includes years prior to 2007, the table also lists GBCs privatized within the decade prior to 2007 . The data were taken from annual reports of the GCA.

\begin{tabular}{|c|c|c|c|c|c|}
\hline & name of company & $\begin{array}{l}\text { annual } \\
\text { revenue in } \\
\text { thousands } \\
\text { of USD in } \\
2007\end{array}$ & $\begin{array}{l}\text { number of } \\
\text { employees } \\
\text { in } 2007\end{array}$ & field & $\begin{array}{l}\text { percentage } \\
\text { held by the } \\
\text { gover- } \\
\text { nment in } \\
2007\end{array}$ \\
\hline 1 & A.T. Communication Channels & 940 & 8 & Transportation and Communication & $100 \%$ \\
\hline 2 & Agrexco Agricultural Export Co. Ltd. & 868,460 & 365 & Agriculture & $50 \%$ \\
\hline 3 & Arim Urban Development Ltd. & 13,040 & 28 & Building, housing and Development & $100 \%$ \\
\hline 4 & Ashdod Port Company Ltd. & 263,670 & 1,275 & Transportation and Communication & $100 \%$ \\
\hline 5 & Ashot-Ashkelon Industries Ltd. & 56,120 & 399 & Defense & $88 \%$ \\
\hline 6 & Ashra the Israel Export Insurance Corporation & 12,440 & 18 & Industry and Commerce & $100 \%$ \\
\hline 7 & Atarim Tourist Development Corp. Tel Aviv Jaffa Ltd. & 6,140 & 23 & Industry and Commerce & $50 \%$ \\
\hline 8 & Bezeq, the Israel Telecommunication Corporation Ltd. & Privatized & Privatized & Transportation and Communication & $0 \%$ \\
\hline 9 & E.M.S. Ltd. & 83,130 & & Electricity and Water & $100 \%$ \\
\hline 10 & Eilat Port Company Ltd. & 27,380 & 112 & Transportation and Communication & $100 \%$ \\
\hline 11 & El Al Israel Airlines Ltd. & Privatized & Privatized & Transportation and Communication & $0 \%$ \\
\hline 12 & Elta Systems Ltd. & 918,750 & 3,407 & Defense & $100 \%$ \\
\hline 13 & Haifa Port Company Ltd. & 210,950 & 1,064 & Transportation and Communication & $100 \%$ \\
\hline 14 & Industrial Development Bank of Israel Ltd. & 26,580 & 43 & Industry and Commerce & $49 \%$ \\
\hline 15 & Insurance Fund for Natural Risks in Agriculture Ltd. & 46,000 & 69 & Agriculture & $50 \%$ \\
\hline 16 & Isorad Ltd. & 12,250 & 20 & Industry and Commerce & $100 \%$ \\
\hline 17 & Israel Aircraft Industries & $3,292,110$ & 12,939 & Defense & $100 \%$ \\
\hline 18 & Israel Bank of Agriculture & 9,780 & 25 & Agriculture & $92 \%$ \\
\hline 19 & Israel Chemicals Ltd. & Privatized & Privatized & Energy and Petroleum & $0 \%$ \\
\hline 20 & Israel Government Coins and Medals Corporation Ltd. & 4,560 & 39 & Industry and Commerce & $100 \%$ \\
\hline 21 & Israel Military Industries Ltd. & 571,440 & 2,966 & Defense & $100 \%$ \\
\hline 22 & Israel Natural Gas Lines Company Ltd. & 7,970 & 69 & Energy and Petroleum & $100 \%$ \\
\hline 23 & Israel Ports Development and Assets Company Ltd. & 172,030 & 105 & Transportation and Communication & $100 \%$ \\
\hline 24 & Israel Postal Company Ltd. & 421,930 & 4,860 & Transportation and Communication & $100 \%$ \\
\hline 25 & Israel Railways Ltd. & 222,770 & 2,107 & Transportation and Communication & $100 \%$ \\
\hline 26 & Life Science Research Israel Ltd. & 4,820 & 47 & Industry and Commerce & $100 \%$ \\
\hline 27 & Lod and Ramleh District Development Company Ltd. & Privatized & Privatized & Energy and Petroleum & $0 \%$ \\
\hline 28 & Matz - The Israel National Roads Company Ltd. & 606,470 & 296 & Industry and Commerce & $100 \%$ \\
\hline 29 & Mekorot Water Co. Ltd. & 708,070 & 2,211 & Electricity and Water & $100 \%$ \\
\hline 30 & Oil Products Pipeline Ltd. & 20,050 & 0 & Energy and Petroleum & $100 \%$ \\
\hline 30 & Oil Refineries Ltd. & Privatized & Privatized & Energy and Petroleum & $0 \%$ \\
\hline 31 & Petroleum and Energy Infrastructures Ltd. & 75,750 & 383 & Energy and Petroleum & $100 \%$ \\
\hline 32 & Pi-Gliloth Petroleum Terminals and Pipelines Ltd. & 9,990 & 76 & Energy and Petroleum & $50 \%$ \\
\hline 33 & Postal Bank Company Ltd. & NA & 0 & Transportation and Communication & $100 \%$ \\
\hline 34 & Rafael Advanced Defense Systems & $1,286,160$ & 5,213 & Defense & $100 \%$ \\
\hline 35 & Rotem Industries Ltd. & 14,890 & 95 & Industry and Commerce & $100 \%$ \\
\hline 36 & The Israel Electric Corporation Ltd. & $4,689,390$ & 12,212 & Electricity and Water & $100 \%$ \\
\hline 37 & The Marine Trust Ltd. & 6,240 & 8 & Building, Housing and Development & $50 \%$ \\
\hline 38 & The National Coal Supply Corporation Ltd. & $1,069,140$ & 26 & Electricity and Water & $99 \%$ \\
\hline 39 & Zim Israel Navigation Company Ltd. & Privatized & Privatized & Transportation and Communication & $0 \%$ \\
\hline
\end{tabular}


Table 2

\section{Summary Statistics of Opportunities Boards Receive and Actions They Take}

This table presents summary statistics, on firm level, for the variables that document the opportunities boards received and the actions they took at board meetings and board-committee meetings of the eleven firms examined. In each column, $\mathrm{N}$ is the cumulative number of all cases examined for all eleven firms analyzed, which aggregate to 2459 decisions and updates or to 1422 decisions, depending on the variable. The variables included in the table (presented in the top row) refer on firm level to the percentage of cases in which (from left to right) the board: discussed an issue categorized under the aggregate topic-subject "business issue" as described in section 3iii; made a decision as opposed to receiving an update; was pres ented with at least two alternatives; requested further information or an update; did not vote in line or voted only partially in line with the CEO's proposal; did not vote unanimously; took a minor initiative (defined in Section 3vi, as cases in which the board slightly modified the original proposal); or took a major initiative (defined in Section 3vi as cas es in which the board took an active part in defining the steps/actions that should be taken by the firm).

\begin{tabular}{|c|c|c|c|c|c|c|c|c|}
\hline & \multicolumn{3}{|c|}{ Opportunities boards received } & \multicolumn{5}{|c|}{ Action boards took } \\
\hline & $\begin{array}{c}\text { business } \\
\text { issue }\end{array}$ & $\begin{array}{l}\text { decision } \\
\text { made }\end{array}$ & $\begin{array}{c}\text { two } \\
\text { alternatives } \\
\end{array}$ & $\begin{array}{c}\text { information/ } \\
\text { update } \\
\text { requested }\end{array}$ & $\begin{array}{l}\text { not/ } \\
\text { partially in } \\
\text { line } \\
\end{array}$ & $\begin{array}{c}\text { not } \\
\text { unanimous } \\
\end{array}$ & $\begin{array}{c}\text { minor } \\
\text { initiative }\end{array}$ & $\begin{array}{c}\text { major } \\
\text { initiative }\end{array}$ \\
\hline average & $25.56 \%$ & $60.83 \%$ & $0.99 \%$ & $7.99 \%$ & $2.45 \%$ & $3.27 \%$ & $4.70 \%$ & $3.41 \%$ \\
\hline median & $26.26 \%$ & $56.99 \%$ & $0.00 \%$ & $5.41 \%$ & $2.56 \%$ & $1.22 \%$ & $4.53 \%$ & $3.01 \%$ \\
\hline minimum & $10.66 \%$ & $42.11 \%$ & $0.00 \%$ & $1.01 \%$ & $0.00 \%$ & $0.00 \%$ & $0.00 \%$ & $0.00 \%$ \\
\hline maximum & $37.84 \%$ & $76.77 \%$ & $4.55 \%$ & $21.13 \%$ & $7.89 \%$ & $18.75 \%$ & $10.88 \%$ & $7.69 \%$ \\
\hline S.D. & $9.04 \%$ & $12.88 \%$ & $1.44 \%$ & $6.71 \%$ & $2.18 \%$ & $5.36 \%$ & $3.21 \%$ & $2.45 \%$ \\
\hline $\begin{array}{l}\text { number of firms } \\
\text { examined }\end{array}$ & 11 & 11 & 11 & 11 & 11 & 11 & 11 & 11 \\
\hline $\mathrm{N}$ & 2459 & 2459 & 1422 & 2459 & 1422 & 1422 & 2459 & 2459 \\
\hline
\end{tabular}


Table 3

\section{Issues Discussed by the Board}

Panel 1 presents the percentage of cases in which each specific topic-subject was discussed, out of the 2459 cases in which the boards of the eleven Israeli firms examined received an update or made a decision at a board meeting or a board-committee meeting. In Panel 1, the items in each column (apart from running subtotals) are to taled at the bottom of the column.

Panel 2 presents a breakdown of the percentage of updates given vers us the perc entage of decisions made, on a topic-subject level. That is, for each to pic-subject the percentage of cases in which the board was provided with an update, as opposed to the percentage of the cas es in which the board made a decision, is presented. The two items in each line total $100 \%$.

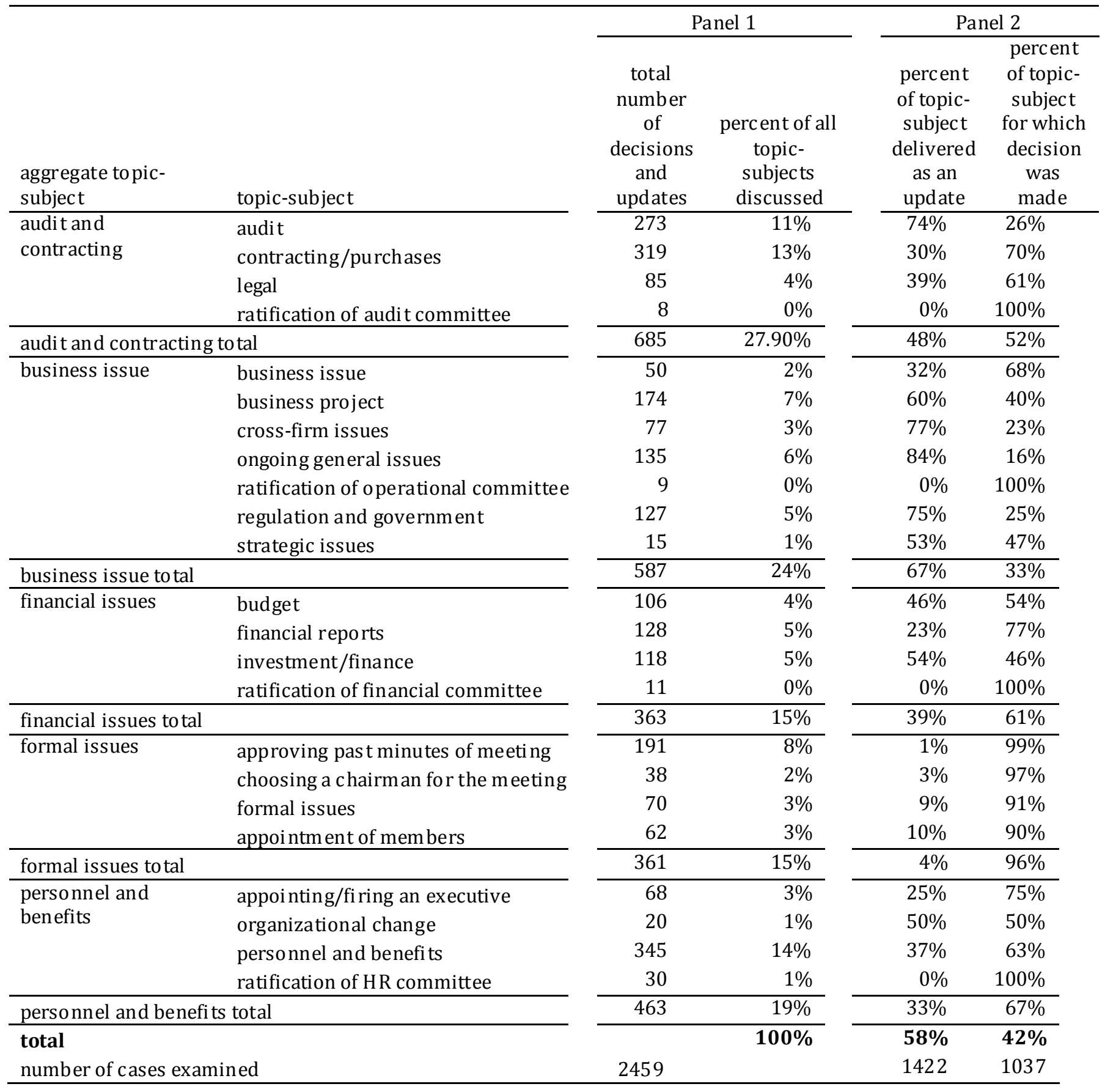


Table 4

\section{Supervisory versus Non -supervisory Issues Discussed by the Boards}

This table categorizes the 2459 topic-subjects discussed at board meetings and board-committee meetings of the eleven Israeli firms examined, distinguishing between those that are of supervisory nature and those that are not. Supervisory topic-subjects were defined as: appointment of members, approving minutes of earlier meetings, audit, choosing a chairman for the meeting, contracting/purchases, financial reports, formal issues, legal, personnel and benefits, ratification of audit committee, ratification of human resources committee, ratification of operational committee, ratification of financial committee, and regulation and government. Non-supervisory topic-subjects were defined as: appointing/firing an executive, budget, business issue, business project, cross-firm issues, investment/finance, ongoing general issues, organizational change, and strategic issues.

The findings indicate that the majority of the work of boards is of supervisory nature, and that this phenomenon is especially pronounced in board-committees.

\begin{tabular}{lcccc}
$\begin{array}{l}\text { At what kind of meeting was the } \\
\text { topic-subject discussed? }\end{array}$ & supervisory & $\begin{array}{c}\text { non- } \\
\text { supervisory }\end{array}$ & $\begin{array}{c}\text { total } \\
\text { percentage }\end{array}$ & $\begin{array}{c}\text { number } \\
\text { of cases }\end{array}$ \\
\hline board & $60 \%$ & $40 \%$ & $100 \%$ & 1,313 \\
board-committee & $79 \%$ & $21 \%$ & $100 \%$ & 1,146 \\
& & & & \\
total number of cases examined & 1,696 & 763 & & 2459 \\
percentage of total & $69 \%$ & $31 \%$ & $100 \%$ & \\
\hline
\end{tabular}


Table 5

\section{Dissension within Boards and Requests to Receive Further Information}

Panel 1 presents the 1422 cases in which the boards of the eleven Israeli firms examined made a decision in a board m eeting or a board-committee m eeting. The table reports, on the topic-subject level, the percentage of cases in which boards voted unanimously. Cases in which one or more board-member did not vote as the others, whether opposing the opinion of the other board-members or abstaining, were coded as nonunanimous votes.

Panel 2 pres ents the 2459 cases in which the boards of the el even Israeli firms examined received an update or made a decision in a board or board-committee meeting. This panel reports, on the to pic-subject level, the perc entage of $c$ ases in which boards requested to receive further information or an update.

\begin{tabular}{|c|c|c|c|c|c|}
\hline \multirow[b]{2}{*}{$\begin{array}{l}\text { aggregate } \\
\text { topic-subject }\end{array}$} & \multirow[b]{2}{*}{ topic-subject } & \multicolumn{2}{|c|}{ Panel 1} & \multicolumn{2}{|c|}{ Panel 2} \\
\hline & & $\begin{array}{c}\text { percent of } \\
\text { cases } \\
\text { decision not } \\
\text { unanimous }\end{array}$ & $\begin{array}{c}\text { number of } \\
\text { cases } \\
\text { (decisions) }\end{array}$ & $\begin{array}{l}\text { perc ent of } \\
\text { cases board } \\
\text { requested } \\
\text { to receive } \\
\text { further } \\
\text { informa- } \\
\text { tion/up- } \\
\text { dates } \\
\end{array}$ & $\begin{array}{c}\text { number of } \\
\text { cases } \\
\text { (decisions } \\
\text { and } \\
\text { updates) }\end{array}$ \\
\hline \multirow{4}{*}{$\begin{array}{l}\text { audit and } \\
\text { contracting }\end{array}$} & audit & $0.0 \%$ & 71 & $26 \%$ & 273 \\
\hline & contracting/purchases & $3.6 \%$ & 223 & $14 \%$ & 319 \\
\hline & legal & $0.0 \%$ & 52 & $9 \%$ & 85 \\
\hline & ratification of audit committee & $0.0 \%$ & 8 & $0 \%$ & 8 \\
\hline \multicolumn{2}{|c|}{ audit and contracting total } & $2.3 \%$ & 354 & $18 \%$ & 685 \\
\hline \multirow{7}{*}{$\begin{array}{l}\text { business } \\
\text { issue }\end{array}$} & business issue & $0.0 \%$ & 34 & $4 \%$ & 50 \\
\hline & business project & $5.7 \%$ & 70 & $14 \%$ & 174 \\
\hline & cross-firm issues & $0.0 \%$ & 18 & $21 \%$ & 77 \\
\hline & ongoing general issues & $0.0 \%$ & 22 & $5 \%$ & 135 \\
\hline & ratification of operational committee & $0.0 \%$ & 9 & $0 \%$ & 9 \\
\hline & regulation and government & $0.0 \%$ & 32 & $9 \%$ & 127 \\
\hline & strategic issues & $14.3 \%$ & 7 & $27 \%$ & 15 \\
\hline \multicolumn{2}{|c|}{ business issue to tal } & $2.6 \%$ & 192 & $11 \%$ & 587 \\
\hline \multirow{4}{*}{$\begin{array}{l}\text { financial } \\
\text { issues }\end{array}$} & budget & $3.5 \%$ & 57 & $17 \%$ & 106 \\
\hline & financial reports & $3.0 \%$ & 99 & $16 \%$ & 128 \\
\hline & investment/finance & $7.4 \%$ & 54 & $8 \%$ & 118 \\
\hline & ratification of financial committee & $0.0 \%$ & 11 & $0 \%$ & 11 \\
\hline \multicolumn{2}{|c|}{ financial issues total } & $4.1 \%$ & 221 & $13 \%$ & 363 \\
\hline \multirow[t]{4}{*}{ formal issues } & approving past minutes of meeting & $0.0 \%$ & 190 & $0 \%$ & 191 \\
\hline & choosing a chairm an for the m eeting & $0.0 \%$ & 37 & $0 \%$ & 38 \\
\hline & formal issues & $0.0 \%$ & 64 & $0 \%$ & 70 \\
\hline & appointment of mem bers & $1.8 \%$ & 56 & $0 \%$ & 62 \\
\hline \multicolumn{2}{|c|}{ formal issues total } & $0.3 \%$ & 347 & $0 \%$ & 361 \\
\hline \multirow{4}{*}{$\begin{array}{l}\text { personnel } \\
\text { and benefits }\end{array}$} & appointing/fi ring an executive & $13.7 \%$ & 51 & $0 \%$ & 68 \\
\hline & organizational change & $0.0 \%$ & 10 & $5 \%$ & 20 \\
\hline & personnel and benefits & $2.8 \%$ & 217 & $11 \%$ & 345 \\
\hline & ratification of HR committee & $0.0 \%$ & 30 & $0 \%$ & 30 \\
\hline \multicolumn{2}{|c|}{ perso nnel and benefits total } & $4.2 \%$ & 308 & $9 \%$ & 463 \\
\hline \multicolumn{2}{|c|}{ total } & $2.5 \%$ & 1422 & $11 \%$ & 2459 \\
\hline
\end{tabular}


Table 6

\section{Boards Voting against CEO's Proposal}

This table presents the 1422 cases in which the boards of the eleven Israeli firms examined made a decision in a board meeting or a board-committee meeting. The table reports, on the to pic-subject level, whether the decision made by the board was not in line, partially in line, or in line with the CEO's initial proposal.

\begin{tabular}{|c|c|c|c|c|c|}
\hline $\begin{array}{l}\text { aggregate } \\
\text { topic- } \\
\text { subject }\end{array}$ & topic-subject & $\begin{array}{c}\text { percent } \\
\text { of cases } \\
\text { not in } \\
\text { line }\end{array}$ & $\begin{array}{l}\text { perc ent } \\
\text { of cases } \\
\text { partially } \\
\text { in line } \\
\end{array}$ & $\begin{array}{l}\text { percent of } \\
\text { cases in } \\
\text { line }\end{array}$ & $\begin{array}{l}\text { number } \\
\text { of cases }\end{array}$ \\
\hline \multirow{4}{*}{$\begin{array}{l}\text { audit and } \\
\text { contracting }\end{array}$} & audit & $0.0 \%$ & $2.8 \%$ & $97.2 \%$ & 71 \\
\hline & contracting/purchases & $0.9 \%$ & $0.9 \%$ & $98.2 \%$ & 223 \\
\hline & legal & $1.9 \%$ & $0.0 \%$ & $98.1 \%$ & 52 \\
\hline & ratification of audit committee & $0.0 \%$ & $0.0 \%$ & $100.0 \%$ & 8 \\
\hline \multicolumn{2}{|c|}{ audit and contracting to tal } & $0.8 \%$ & $1.1 \%$ & $98.0 \%$ & 354 \\
\hline \multirow{7}{*}{$\begin{array}{l}\text { business } \\
\text { issue }\end{array}$} & business issue & $0.0 \%$ & $0.0 \%$ & $100.0 \%$ & 34 \\
\hline & business project & $0.0 \%$ & $1.4 \%$ & $98.6 \%$ & 70 \\
\hline & cross-firm issues & $0.0 \%$ & $0.0 \%$ & $100.0 \%$ & 18 \\
\hline & ongoing general issues & $0.0 \%$ & $0.0 \%$ & $100.0 \%$ & 22 \\
\hline & ratification of operational committee & $0.0 \%$ & $0.0 \%$ & $100.0 \%$ & 9 \\
\hline & regulation and government & $0.0 \%$ & $3.1 \%$ & $96.9 \%$ & 32 \\
\hline & strategic issues & $0.0 \%$ & $0.0 \%$ & $100.0 \%$ & 7 \\
\hline \multicolumn{2}{|c|}{ business issue total } & $0.0 \%$ & $1.0 \%$ & $99.0 \%$ & 192 \\
\hline \multirow{4}{*}{$\begin{array}{l}\text { financial } \\
\text { issues }\end{array}$} & budget & $1.8 \%$ & $3.5 \%$ & $94.7 \%$ & 57 \\
\hline & financial reports & $0.0 \%$ & $4.0 \%$ & $96.0 \%$ & 99 \\
\hline & investment/finance & $0.0 \%$ & $5.6 \%$ & $94.4 \%$ & 54 \\
\hline & ratification of financial committee & $0.0 \%$ & $0.0 \%$ & $100.0 \%$ & 11 \\
\hline \multicolumn{2}{|c|}{ financial issues total } & $0.5 \%$ & $4.1 \%$ & $95.5 \%$ & 221 \\
\hline \multirow{4}{*}{$\begin{array}{l}\text { formal } \\
\text { issues }\end{array}$} & approving past minutes of meeting & $0.0 \%$ & $0.0 \%$ & $100.0 \%$ & 190 \\
\hline & choosing a chairm an for the meeting & $0.0 \%$ & $0.0 \%$ & $100.0 \%$ & 37 \\
\hline & formal issues & $0.0 \%$ & $0.0 \%$ & $100.0 \%$ & 64 \\
\hline & appointment of members & $1.8 \%$ & $1.8 \%$ & $96.4 \%$ & 56 \\
\hline \multicolumn{2}{|c|}{ formal issues total } & $0.3 \%$ & $0.3 \%$ & $99.4 \%$ & 346 \\
\hline \multirow{4}{*}{$\begin{array}{l}\text { perso nnel } \\
\text { and } \\
\text { benefits }\end{array}$} & appointing/firing an executive & $7.8 \%$ & $2.0 \%$ & $90.2 \%$ & 51 \\
\hline & organizational change & $0.0 \%$ & $0.0 \%$ & $100.0 \%$ & 10 \\
\hline & personnel and benefits & $1.8 \%$ & $2.3 \%$ & $95.9 \%$ & 217 \\
\hline & ratification of HR committee & $0.0 \%$ & $0.0 \%$ & $100.0 \%$ & 30 \\
\hline \multicolumn{2}{|c|}{ personnel and benefits total } & $2.6 \%$ & $1.9 \%$ & $95.5 \%$ & 308 \\
\hline \multicolumn{2}{|l|}{ total } & $0.9 \%$ & $1.5 \%$ & $\mathbf{9 7 . 5 \%}$ & 1422 \\
\hline
\end{tabular}


Table 7

\section{Boards Taking an Initiative}

This table reports on the to pic-subject level, for the 2459 cases in which the boards of the eleven Israeli firms examined received an update or made a decision in a board meeting or a board -committee meeting, whether the boards took no action, a minor initiative, or a major initiative. "Minor initiative" was defined as a case in which the board slightly modified the original proposal. "Major initiative" was defined as a case in which the board took an active part in defining the steps/actions that should be taken by the firm. "No action" are all cases in which neither a minor initiative nor a major one was taken. A more detailed description of these variables is provided in Section 3vi.

\begin{tabular}{|c|c|c|c|c|c|}
\hline $\begin{array}{l}\text { aggregate } \\
\text { topic- } \\
\text { subject }\end{array}$ & topic-subject & no action & $\begin{array}{c}\text { minor } \\
\text { initiative }\end{array}$ & $\begin{array}{c}\text { major } \\
\text { initiative }\end{array}$ & $\begin{array}{c}\text { number of } \\
\text { cases }\end{array}$ \\
\hline \multirow{4}{*}{$\begin{array}{l}\text { audit and } \\
\text { contracting }\end{array}$} & audit & $83.5 \%$ & $7.7 \%$ & $8.8 \%$ & 273 \\
\hline & contracting/purchases & $91.2 \%$ & $6.9 \%$ & $1.9 \%$ & 319 \\
\hline & legal & $90.6 \%$ & $7.1 \%$ & $2.4 \%$ & 85 \\
\hline & ratification of audit committee & $100.0 \%$ & $0.0 \%$ & $0.0 \%$ & 8 \\
\hline \multicolumn{2}{|c|}{ audit and contracting to tal } & $88.2 \%$ & $7.2 \%$ & $4.7 \%$ & 685 \\
\hline \multirow{7}{*}{$\begin{array}{l}\text { business } \\
\text { issue }\end{array}$} & business issue & $98.0 \%$ & $0.0 \%$ & $2.0 \%$ & 50 \\
\hline & business project & $91.4 \%$ & $6.9 \%$ & $1.7 \%$ & 174 \\
\hline & cross-firm issues & $83.1 \%$ & $6.5 \%$ & $10.4 \%$ & 77 \\
\hline & ongoing general issues & $100.0 \%$ & $0.0 \%$ & $0.0 \%$ & 135 \\
\hline & ratification of operational committee & $88.9 \%$ & $11.1 \%$ & $0.0 \%$ & 9 \\
\hline & regulation and government & $92.9 \%$ & $3.9 \%$ & $3.1 \%$ & 127 \\
\hline & strategic issues & $80.0 \%$ & $13.3 \%$ & $6.7 \%$ & 15 \\
\hline \multicolumn{2}{|c|}{ business issue to tal } & $92.8 \%$ & $4.3 \%$ & $2.9 \%$ & 587 \\
\hline \multirow{4}{*}{$\begin{array}{l}\text { financial } \\
\text { issues }\end{array}$} & budget & $90.6 \%$ & $5.7 \%$ & $3.8 \%$ & 106 \\
\hline & financial reports & $85.2 \%$ & $9.4 \%$ & $5.5 \%$ & 128 \\
\hline & investment/finance & $92.4 \%$ & $7.6 \%$ & $0.0 \%$ & 118 \\
\hline & ratification of financial committee & $100.0 \%$ & $0.0 \%$ & $0.0 \%$ & 11 \\
\hline \multicolumn{2}{|c|}{ financial issues total } & $89.5 \%$ & $7.4 \%$ & $3.0 \%$ & 363 \\
\hline \multirow{4}{*}{$\begin{array}{l}\text { formal } \\
\text { issues }\end{array}$} & approving past minutes of meeting & $100.0 \%$ & $0.0 \%$ & $0.0 \%$ & 191 \\
\hline & choosing a chairm an for the meeting & $100.0 \%$ & $0.0 \%$ & $0.0 \%$ & 38 \\
\hline & formal issues & $98.6 \%$ & $0.0 \%$ & $1.4 \%$ & 70 \\
\hline & appointm ent of members & $93.5 \%$ & $1.6 \%$ & $4.8 \%$ & 62 \\
\hline \multicolumn{2}{|c|}{ formal issues total } & $98.6 \%$ & $0.3 \%$ & $1.1 \%$ & 361 \\
\hline \multirow{4}{*}{$\begin{array}{l}\text { perso nnel } \\
\text { and } \\
\text { ben efits }\end{array}$} & appointing/firing an executive & $63.2 \%$ & $8.8 \%$ & $27.9 \%$ & 68 \\
\hline & organizational change & $90.0 \%$ & $0.0 \%$ & $10.0 \%$ & 20 \\
\hline & personnel and benefits & $89.6 \%$ & $5.2 \%$ & $5.2 \%$ & 345 \\
\hline & ratification of HR committee & $100.0 \%$ & $0.0 \%$ & $0.0 \%$ & 30 \\
\hline \multicolumn{2}{|c|}{ personnel and benefits total } & $86.4 \%$ & $5.2 \%$ & $8.4 \%$ & 463 \\
\hline \multicolumn{2}{|c|}{ total percentage } & $90.7 \%$ & $5.1 \%$ & $4.2 \%$ & \\
\hline \multicolumn{2}{|c|}{ total number of cases examined } & 2,230 & 103 & 126 & 2459 \\
\hline
\end{tabular}


Table 8

\section{Boards Making Decisions versu s Receiving Updates Concerning Business Issues}

This table presents pooled OLS regressions that examine whether the boards of the eleven Israeli firms examined tended to receive updates, rather than make decisions, with regard to business issues. The dependent binary variable documents whether a decision was made, as opposed to the option that an update was provided. Regression 1 does not control for fixed effects across firms; Regression 2 does. Hence, the independent variables that are fixed on firm level (log income T-1, number of board-members and log number of meetings) are only included in Regression 1. All variables are defined in List 1. For each variable presented, the first line presents the coefficient and the second line presents robust standard errors (in parentheses). ${ }^{* *}, * *, *$, indicate significance at the $0.01,0.05$, and 0.10 level, respectively. Constant included but not presented.

The results indicate that boards are significantly more likely to receive an update, as opposed to making a decision, with regard to business issues.

\begin{tabular}{lcc}
\hline & \multicolumn{2}{c}{ Was a decision made? } \\
\cline { 2 - 3 } & $(1)$ & $(2)$ \\
\hline was business issue & $-.356^{* * *}$ & $-.351^{* *}$ \\
was committee meeting & $(.023)$ & $(.023)$ \\
& $-.112^{* * *}$ & $.100^{* * *}$ \\
interregnum & $(.020)$ & $(.020)$ \\
& .044 & $-.090^{*}$ \\
log income T-1 & $.028)$ & $(.038)$ \\
& $.010^{* *}$ & \\
number of board-members & $(.013)$ & \\
& .012 & \\
log number of meetings & $(.005)$ & \\
& -.296 & \\
only decisions included & $.068)$ & \\
number of observations & & no \\
adjusted R-square & 2459 & 1422 \\
significance & 0.104 & 0.122 \\
\hline
\end{tabular}


List 1

Definitions of Variables for Table 8

\begin{tabular}{|c|c|}
\hline Name of variable & Definition \\
\hline \multicolumn{2}{|l|}{ Dependent variables } \\
\hline Minor initiative & $\begin{array}{l}\text { A binary variable which equals } 1 \text { in cases in which a minor initiative was } \\
\text { taken by the board. A minor initiative refers to a case in which the boards } \\
\text { slightly modified the original proposal. This variable is further described in } \\
\text { Section 3vi. }\end{array}$ \\
\hline Major initiative & $\begin{array}{l}\text { A binary variable which equals } 1 \text { in cases in which a major initiative was } \\
\text { taken by the board. A major initiative refers to a case in which the board took } \\
\text { an active part in defining the steps/actions that should be taken by the firm. } \\
\text { This variable is further described in Section 3vi. }\end{array}$ \\
\hline Not/partially in line & $\begin{array}{l}\text { A binary variable which equals } 1 \text { in cases in which the board did not vote in } \\
\text { line or voted partially in line with the CEO's/managem ent's initial proposal. } \\
\text { This variable is further described in Section 3iv. }\end{array}$ \\
\hline $\begin{array}{l}\text { Information/ update } \\
\text { requested }\end{array}$ & $\begin{array}{l}\text { A binary variable which equals } 1 \text { in cases in which the board requested to } \\
\text { receive further information or updates. This variable is further described in } \\
\text { Section 3v. }\end{array}$ \\
\hline Not unanimo us & $\begin{array}{l}\text { A binary variable which equals } 1 \text { in cases in which the vote taken by the } \\
\text { board was unanimous. This variable is further described in Section 3viii. }\end{array}$ \\
\hline Decision & $\begin{array}{l}\text { A dummy which equals } 1 \text { in cases in which the board made a decision, and } 0 \\
\text { if it received an update. This variable is further described in Section } 3 \mathrm{i} \text {. }\end{array}$ \\
\hline \multicolumn{2}{|l|}{ Ind ep end ent va riables } \\
\hline Was business issue & $\begin{array}{l}\text { A dummy which equals } 1 \text { if the topic-subject discussed belonged to the } \\
\text { aggregate to pic-subject "business issue" (as defined in Section 3iii) and } 0 \\
\text { otherwise. }\end{array}$ \\
\hline $\begin{array}{l}\text { Was committee } \\
\text { meeting }\end{array}$ & $\begin{array}{l}\text { A dummy which equals } 1 \text { if the meeting at which the topic-subject was } \\
\text { discussed was a board-committee meeting and } 0 \text { if it was a board meeting. }\end{array}$ \\
\hline Interregnum & $\begin{array}{l}\text { A dummy which equals } 1 \text { if at the time the to pic-subject was discussed the } \\
\text { company had no CEO, and } 0 \text { if it had a serving CEO. }\end{array}$ \\
\hline Log income $\mathrm{T}-1$ & $\begin{array}{l}\text { Log of the annual income of the firm, for the prec eding year for which the } \\
\text { minutes were examined. Fixed figure for each firm. }\end{array}$ \\
\hline $\begin{array}{l}\text { Number of board- } \\
\text { members }\end{array}$ & $\begin{array}{l}\text { The average number of board-m embers who served for at least six months } \\
\text { during the calen dar year exami ned. Fixed fi gure for each firm. }\end{array}$ \\
\hline $\begin{array}{l}\text { Log number of } \\
\text { meetings }\end{array}$ & $\begin{array}{l}\text { The log of the total number of board me etings and board-committee } \\
\text { meetings held during one cal endar year. Fixed figure for each firm. }\end{array}$ \\
\hline
\end{tabular}




\section{Appendix: Representativeness of the Findings}

A point which must be addressed is if, and to what extent, the findings - which are all based on data of companies in which the Israeli government holds a significant portion of the shares - reflect the occurrences and outcomes of boards of listed companies in general. Table A addresses this question by presenting a comparison between Israeli companies engaged in business activities in which the government holds shares (GBCs) and listed companies (LCs).

Table A demonstrates that the settings in which the GBCs operate are no less demanding in comparison to those in which LCs operate. As the previous section demonstrates, both types of companies are directly impacted by macro factors, i.e., they do not operate in a secluded bubble, and they exhibit similar profitability margins.

Additionally, the figures regarding the median tenure of CEOs presented in Table A indicate that CEOs of GBCs are less able to entrench themselves, in comparison to their peers in listed companies (the median tenure for CEOs in GBCs is 3.1 years, while for LCs this figure equals 6.3). This provides support for the argument that CEOs of GBCs, and probably their boards too, must deal with challenges that are not easier to handle than those their counterparts in LCs must handle. Moreover, as the median number of annual board meetings indicates (12 for GBCs versus 8 for LCs), boards of GBCs work at least as intensively as their peers in LCs.

What is more, the GBCs examined share an important characteristic with the American and English companies - neither type of company has an active owner dictating how business should be run. ${ }^{16}$ In the case of American and English firms this is the case

\footnotetext{
16 I thank Prof. Oliver Hart for pointing out this issue to me, in a very bri ef conversation.
} 
because ownership is dispersed. In the case of the GBCs this is the case because although the ministers are responsible for regulation pertaining to the firm, which is of course of great importance to the firm, nevertheless they are not involved, formally or in practice, in the actual ongoing management of the firm. That, in turn, allows the board, to operate independently.

Furthermore, because of the unique board nomination mechanism which prevails in the firms examined, described in Chapter2, i.e., the fact that boards are, in practice, chosen by different ministers for every term, they can be relatively independent. This is because board-members are aware of the fact that the next time they will be up for possible re-nomination there will be a new "boss" (minister), who will probably not be too familiar with their record of contribution to the firm.

Last, Supplement D, which presents a small sample of the situations documented in the minutes, may suggest that the situations encountered by the boards examined can easily be encountered by other boards as well.

In sum, although differences exist between GBCs and LCs, boards of both types of firms are responsible for the overall management of the company, advising and monitoring the CEO and the management. The analysis in this study addresses, in large measure, issues that should equally affect all boards: the dynamics among the board-members themselves and also the dynamics between the board-members and the CEO. In light of the points discussed in this section and the ones presented in Table A, and also based on informal discussions with board-members who sit on both types of boards, although GBCs may not be as aggressively profit-oriented as LCs, nevertheless the board dynamics in GBCs should not be expected to be any softer or non-assertive than those that prevail in LCs. 
Table A

Comparison between Government Business Companies (GBCs) and Listed Companies (LCs)

\begin{tabular}{|c|c|c|}
\hline Variable & GBCs & LCs \\
\hline Responsibility of board & $\begin{array}{l}\text { Overall management of the } \\
\text { company, advising and monitoring. }\end{array}$ & As in GBCs. \\
\hline $\begin{array}{l}\text { Median number of annual board } \\
\text { meetings }{ }^{17}\end{array}$ & 12 meetings. & 8 meetings. \\
\hline $\begin{array}{l}\text { Who in reality appoints board- } \\
\text { members? }\end{array}$ & The ministers. & $\begin{array}{l}\text { Current board, with the } \\
\text { involvement of the CEO. }\end{array}$ \\
\hline $\begin{array}{l}\text { Minimal qualifications of board- } \\
\text { members }\end{array}$ & Exist, as specified in Section 3.1. & Generally do not exist. \\
\hline Who appoints the CEO? & The board. & As in GBCs. \\
\hline Median tenure of $\mathrm{CEO}^{18}$ & 3.1 years. & 6.3 years. \\
\hline Existence of endogeneity & $\begin{array}{l}\text { Does not prevail, because different } \\
\text { government ministers nominate re- } \\
\text { nominate board-members } \\
\text { regardless of previous firm } \\
\text { performance (see Section 3.1.1) }\end{array}$ & $\begin{array}{l}\text { Prevails, because the board } \\
\text { practically re-elects itself. }\end{array}$ \\
\hline $\begin{array}{l}\text { Is there a large dominant } \\
\text { shareholder? }\end{array}$ & Yes, the government. & $\begin{array}{l}\text { Dispersed ownership in the US } \\
\text { and Britain, concentrated in } \\
\text { Europe. }\end{array}$ \\
\hline $\begin{array}{l}\text { Compensation board-members } \\
\text { receive }\end{array}$ & Low compensation. & High compensation. \\
\hline Goal of firm & $\begin{array}{l}\text { Operate efficiently without gouging } \\
\text { the public. }\end{array}$ & Maximize profit. \\
\hline Profitability margins & $\begin{array}{l}\text { Approximately 6\% (see Supplement } \\
\text { B). }\end{array}$ & $\begin{array}{l}\text { Approximately } 7 \% \text { (see } \\
\text { Supplement B). }\end{array}$ \\
\hline Macro factors & $\begin{array}{l}\text { Impact profitability, not dividends } \\
\text { (see Supplement B). }\end{array}$ & $\begin{array}{l}\text { Impact profitability and } \\
\text { dividends (see Supplement B). }\end{array}$ \\
\hline \multicolumn{3}{|c|}{$\begin{array}{l}17 \text { The median number of annual board m eetings for GBCs refers to the el even companies examined in this } \\
\text { paper. The comparable figure pres ented for listed companies was taken from the Spencer Stuart US Board } \\
\text { Index (2010), which examines corporate governance among the S\&P } 500 \text { companies. } \\
18 \text { The median tenure rate presented for CEOs of GBCs was calculated by the author based on data pertaining } \\
\text { to all GBCs, for the years 1997-2007, taken from an internal database of the Government Com pani es Authority. } \\
\text { The median tenure rate presented for CEOs of LCs was taken from Favaro et al. (2010), which examines "CEO } \\
\text { succession among the world's top 2,500 public compani es". }\end{array}$} \\
\hline
\end{tabular}




\section{Bibliography}

1. Adams, Renee B., Benjamin E. Hermalin, and Michael S. Weisbach, 2010. The Role of Boards of Directors in Corporate Governance: A Conceptual Framework and Survey, Journal of Economic Literature 48 (1), 58-107.

2. Adams, Renee B. and Daniel Ferreira, 2007. A Theory of Friendly Boards, Journal of Finance 62(1), 217-250.

3. Almazan, Andres and Javier Suarez, 2003. Entrenchment and Severance Pay in Optimal Governance Structures, Journal of Finance 58 (2), 519-547.

4. Dominguez-Martinez, Silvia, Otto H. Swank, and Bauke Visser (2008). In Defense of Boards, Journal of Economics and Management Strategy 17(3), 667-682.

5. Fama, Eugene F. and Michael C. Jensen, 1983. Separation of Ownership and Control, Journal of Law and Economics 26(2), 301-325.

6. Fama, Eugene F., 1980. Agency Problems and the Theory of the Firm, Journal of Political Economy 88(2), 288-307.

7. Government Companies Authority (Israel), Annual Reports on the Government Companies, 1997-2007.

8. Graham, John R. and Campbell R. Harvey, 2001. The Theory and Practice of Corporate Governance: Evidence from the Field, Journal of Financial Economics 60, 187-243

9. Graziano, Clara and Annalisa Luporini, 2003. Board Efficiency and Internal Corporate Control Mechanisms, Journal of Economics and Management Strategy 12(4), 495-530

10.Greene, William, 2008. Econometric Analysis, 6th Edition, Upper Saddle River, New Jersey: Prentice Hall. 
11. Harris, Milton and Artur Raviv, 2008. A Theory of Board Control and Size. The Review of Financial Studies 21(4), 1797-1832.

12 .Hermalin, Benjamin E. and Michael S. Weisbach, 1998. Endogenously Chosen Boards of Directors and Their Monitoring of the CEO, American Economic Review 88(1), 96-118.

13 .Hermalin, Benjamin E., 2005. Trends in Corporate Governance, Journal of Finance 60 (5), 2351-2384.

14 .Holmstrom, Bengt, 1979. Moral Hazard and Observability, The Bell Journal of Economics 10(1), 74-91.

15 .Jensen, Michael C. and William H. Meckling, 1976. Theory of the Firm: Managerial Behavior, Agency Costs, and Ownership Structure, Journal of Financial Economics 3(4), 305-350.

16. Klein, April, 1998. Firm Performance and Board Committee Structure, Journal of Law and Economics 41, 275-303.

17.Krippendorff, Klaus, 2004. Content-analysis: An Introduction to Its Methodology, Thousand Oaks, CA: Sage Publications.

18.Laux, Christian and Volker Laux, 2008. Board Committees, CEO Compensation, and Earnings Management. Working Paper.

19.Laux, Volker, 2008. Board Independence and CEO Turnover, Journal of Accounting Research 46, 137-171.

20 .Lieblich, Amia, Rivka Tuval-Mashiach, and Tamar Zilber, 1998. Narrative Research: Reading, Analysis, and Interpretation, Thousand Oaks, CA: Sage Publications.

21 .Lipton, Martin and Jay W. Lorsch, 1992. A Modest Proposal for Improved Corporate Governance, Business Lawyer 48, 59- 77. 
22 .Leblanc, Richard and James Gilies, 2005. Inside the Boardroom: How Boards Really Work and the Coming Revolution in Corporate Governance, Toronto: John Wiley and Sons Canada.

23.Lorsch, Jay W. and Elizabeth Maclver, 1989. Pawns or Potentates: The Reality of America's Corporate Boards, Boston: Harvard Business School Press.

24 .Mace, Myles L., 1971. Directors: Myth and Reality, Boston: Harvard Business School Press.

25.Merchant, Keneth and Katherina Pick, 2010. Biases and Other Pathologies in the Boardroom, New York: Business Expert Press.

26.Patton, Arch and John C. Baker, 1987. Why Won't Directors Rock the Boat?, Harvard Business Review 65(6), 10-18.

27. Shivdasani, Anil and David Yermack, 1999. CEO Involvement in the Selection of New Board-members: An Empirical Analysis. Journal of Finance 54, 1829-1853.

28 .Shrader, Charles B., Virginia B. Blackburn, and Paul Iles, 1997. Women in Management and Firm Financial Performance: An Exploratory Study, Journal of Managerial Issues 9, 355-372.

29. Song, Fenghua and Anjan V. Thakor, 2006. Information Control, Career Concerns, and Corporate Governance, Journal of Finance 61(4), 1845-1896.

30 .Spencer Stuart, 2010. Spencer Stuart US Board Index 2010, Chicago: Spencer Stuart.

31.Stiles, Philip and Bernard Taylor, 2001. Boards at Work: How Directors View Their Roles and Responsibilities, Oxford: Oxford University Press.

32. Stiles, Philip, 2001. The Impact of the Board on Strategy: An Empirical Examination, Journal of Management Studies, 38(5), 627-650. 
33.Tirole, Jean, 1986. Hierarchies and Bureaucracies: On the Role of Collusion in Organizations, Journal of Law, Economics, and Organization 2(2), 181-214.

34.Wang, Peiji, 2009. Financial Econometrics, $2^{\text {nd }}$ ed., Routledge: NY.

35. Warther, Vincent A., 1998. Board Effectiveness and Board Dissent: A Model of the Board's Relationship to Management and Shareholders, Journal of Corporate Finance 4(1), 53-70.

36.Wooldridge, Jeffrey M., 2009. Introductory Econometrics: A Modern Approach, $4^{\text {th }}$ ed. Mason, Ohio: South-Western Cengage Learning.

37 .Yermack, David, 2004. Remuneration, Retention, and Reputation Incentives for Outs ide Directors, Journal of Finance 59, 2281-308. 
List of Supplements (to be made available via Internet):

Supplement A: Detailed Description of Companies Engaged in Business Activities in which the Israeli Government Holds Shares

Supplement B: Israeli Business Companies - Government versus Private

Supplement C: Complete Coding Guidelines

Supplement D: Qualitative Examples 


\section{Supplement A: Detailed Description of Companies Engaged in Business Activities in which the Israeli Government Holds Shares}

As mentioned, the data analyzed in this study pertain to business firms in which the Israeli government holds shares; these shall be referred to as GBCs. This section presents the setting in which these companies operate, and provides background concerning their boards.

Ninety-two government-owned companies operate in Israel in various fields, including infrastructure, military technology, construction/housing and services. All companies are overseen by the Government Companies Authority (GCA), which carries out the role of the government as a shareholder. ${ }^{19}$ Of the ninety-two companies in which the Israeli government holds shares, thirty-three are categorized by the GCA as "business companies". In the present study, only companies of the latter category are examined. These companies are required, by law, to manage their business in a way that will maximize their profits.

Table 1 presents key 2007 figures for all companies engaged in business activities in which the Israeli government held shares in that year, and also lists, (but without such figures) firms that were GBCs during the preceding decade, but were privatized prior to 2007. As is evident, the size of these companies varies greatly: some companies employ only tens of employees, whereas others employ more than ten thousand. The annual income of the smaller GBCs is just a few million USD, whereas the comparable figure for the

${ }^{19}$ Miriam Schwartz-Ziv worked in the Gov ernment Companies Authority from 2006 until 2010. 
larger firms is one to four billion USD. The latter firms are very large, according to Israeli standards..$^{20}$

All firms examined have one-tier boards. Generally, the board may formally consist of six to twelve members (depending on the company), but in practice seven to ten is most common. There are companies that for certain periods did not have the minimum number of board-members required to allow a quorum for a board meeting.

Israel's 1999 "Corporation Law" and 1975 "Government Companies Law" (henceforth: GCL), which both apply to the firms examined, detail the duties incumbent upon their boards. Both laws stress that the board must determine the company's policy. In addition, both laws stress that the board must monitor the CEO.

Furthermore, the GCL specifies additional tasks the board must carry out: determine the company's budget, discuss the financial reports, determine the long-term program, approve the number of employees, choose and appoint the CEO and the auditor, and approve the recruitment of executives the CEO has recommended to recruit. The GCL also ordains that the CEO may not be a board-member - yet in practice, as is evident from the minutes examined, he is present in virtually all meetings of the board and its committees. Concerning "business companies", which are the firms examined in this study, the GCL explicitly requires that "the firm operate according to business considerations just as firms with no government shareholder do". ${ }^{21}$

\footnotetext{
20 The median income of 662 companies that were traded at the Tel-Aviv Stock Exchange in 2007, and for which data is available, was 36 million USD; the average figure was 265 million USD. In 2007, only six companies traded on the TASE had income that exceeded that of the Israel El ectricity Company, the largest government com pany in Israel.

${ }^{21}$ All translations from Hebrew in this paper are by Miriam Schwartz-Ziv.
} 
The by-laws of each of the companies examined define which ministers appoint the directors of the company; in most cases it is the Minister of Finance and one additional relevant minister. In certain cases, the by-laws state that some of the directors must be employees of the ministries, and/or representatives of the company's employees, but in no case may more than two of the latter sit on a board. In addition, a representative of the GCA sits on the board. The GCL grants him a status equal to that of a board-member, yet, he is not entitled to vote.

The GCL requires that in companies in which the government holds more than half the votes in the general stockholders' meetings, board-member must be at least twenty-five years old; be residents of Israel; have degrees in business, economics, law, accounting, engineering, public service, or any other field relevant to the firm; and have at least two years of relevant experience or experience in a senior position. The requirements regarding the chairman are even stricter.

The abovementioned requirements regarding the minimal qualifications of boardmembers are enforced rather carefully by a professional committee. Hence, Dina Merrill, the 83-year-old actress who sat on the board of Lehman Brothers for 18 years, could not have been nominated to serve as a board-member on a board of a GBC, even if she were a resident of Israel.

Since 1993, the GCL requires that the board of firms of companies in which the Israeli Government holds more than half the votes in the general stockholders' meetings be composed in such a way that gives appropriate representation to women (i.e., that they comprise approximately $50 \%$ of the board). In 2000 , a parallel requirement was made with 
regard to Arabs (i.e., that they comprise approximately $20 \%$ of the board, as of the Israeli population in general).

The only compensation given to board-members is a fixed compensation for each board or board-committee meeting they attend. This compensation amounts to $\$ 185$ $\$ 350$, depending upon the size of the company. ${ }^{22}$ Although this financial compensation is not high, there are always candidates interested in nomination to boards of GBCs, since such positions provide, inter alia, status and the expansion and strengthening of one's professional network, and also enable the development of an expertise in demand in the better-paying private sector. Fama and Jensen (1983), Lorsh and MacIver (1989), and Yermack (2004) further elaborate on the advantages that accrue to board-members.

\section{Endogeneity}

As stated above, the board-nomination mechanism which prevails in the companies examined does not entail the mechanism plagued with endogeneity, which - as stressed by Hermalin and Weisbach $(1998,2003)$ and by Bebchuck and Fried (2006) - exists in most companies. Specifically, in most firms the makeup of boards and their actions are fundamentally intertwined: board-members are chosen and re-elected by the board, with high formal and informal involvement of the management (Shivdasani and Yermack, 1999). This mechanism may affect the way board-members carry out their responsibilities, since they are concerned with increasing their chances of being re-nominated.

\footnotetext{
22 In small and medium companies, the chairman is not employed on a full-time basis, and he receives compensation only on a basis of meeting he actually attended, compensation which is approximately $20 \%$ higher than that paid to board members. In large companies, the chairman is employed on a full-time basis, and accordingly receives (only) a monthly salary. State employees or company employees receive no additional remuneration for serving as board-m embers.
} 
However, in the firms examined the board-members are elected for a period of three years, and in Israel governments rarely last that long: Although a government is elected for a four-year term of office, since 1996 no government has lasted its full term. Hence, board-members are aware that the question of their re-nomination will be decided on the basis of their connections and access to the ministers of the next government regardless of firm performance, and their specific contribution to the firm.

The following analysis was conducted to establish the argument that endogeneity does not exist in the firms examined, i.e., that board-members do not resign following weak firm performance, and that they will not be re-nominated following strong firm performance:

A panel data was constructed, pertaining to the 1,090 board-members of GBCs whose terms of service ended between 1997 and 2007. Two dependent binary variables were defined: (1) a variable indicating whether a board-member served the full three-year term for which she was nominated (termed as board-member resigned), ${ }^{23}$ and (2) a variable indicating whether a board-member was re-nominated at the end of the term for which she was nominated (termed as board-member re-elected).

The independent variable controlling for previous firm performance is EBITDA/income at T-1 (i.e., EBITDA/income in the preceding year). The other independent variables included are GDP change, CPI change, consumption change, wage change, election

\footnotetext{
${ }^{23}$ It is not possible to distinguish between cases in which board-members resigned, and those in which they were fired or were strongly advised to resign. Yet cases of firing or of such strong advice are very rare. Only government ministers have the right to fire a board-member, and usually they exercise that right only when the GCA has strong reason to believe that the board-m ember wantonly violated laws or rules. Accordingly, in the vast majority of cases in which board-members finished their term early, they resigned and were not fired. Hence, this limitation should not significantly impinge upon the analysis.
} 
year T-1, and log income T-1. All variables are further defined in List I. For each of the 1,090 cases examined, each of these independent variables reflects data referring to the specific year each election-term actually ended. Analysis via logistic regressions led to similar results, not reported.

As the results in Table I indicate, in all sets of regressions conducted, in which the dependant variable were binary variables documenting early resignation or re-election of board-members, prior firm performance did not enter significantly. These results indicate that weak firm performance did not bring about the resignation of board-members, and that strong firm performance was not followed by re-nomination of board-members. This provides support for the argument that in the firms examined, the common problem of endogeneity does not prevail. 
Table I

\section{Firm Performance and Board Resignation/Re-nomination}

In order to assess endogeneity in the firms studied, this table examines whether board -mem bers resigned or were re-elected because of previous firm performance. The table analyzes panel data pertaining to the 1,090 board appointees whose terms of service ended between 1997 and 2007, in business compani es in which the Israeli government held shares during these years. The dependent variables examined were whether the board-member did not serve the full three-year term for which he was nominated (regressions 1-2) and whether a board-member was re-nominated at the end of the term (regressions 3-4). The independent variables included control for previous firm performance measured by EBITDA/income T-1, i.e., the EBITDA/income ratio for the year preceding the resignation/re-nomination. All variables are further defined in List I. For each of the 1,090 cases examined, each of the ind ependent variables reflects data referring to the specific year each election-term actually ended. In all regressions, fixed effects on firm level are controlled for, hence, robust clustered errors on firm level are reported. Regressions 1 and 3 include year dummies, while 2 and 4 include macro factors. For each variable presented, the first line pres ents the coefficients and the second line presents robust standard errors (in parentheses). ${ }^{* *}, * *, *$, indicate significance at the $0.01,0.05$, and 0.10 level, respectively. Cons tant included but not presented.

The results indicate that in the firms examined previous firm performance does not impact significantly upon the likelihood that board-members resign or be re-elected. This implies that endogeneity is not prevalent in thes e firms.

\begin{tabular}{|c|c|c|c|c|}
\hline & \multicolumn{2}{|c|}{ board-m ember resigned } & \multicolumn{2}{|c|}{ board-m ember re-elected } \\
\hline & $(1)$ & $(2)$ & $(3)$ & $(4)$ \\
\hline EBITDA/income T-1 & $\begin{array}{l}.000 \\
(.000)\end{array}$ & $\begin{array}{c}.000 \\
(.003)\end{array}$ & $\begin{array}{l}.000 \\
(.002)\end{array}$ & $\begin{array}{c}.000 \\
(.002)\end{array}$ \\
\hline $\log$ income $\mathrm{T}-1$ & $\begin{array}{l}-.040 \\
(.102)\end{array}$ & & $\begin{array}{c}-.082 \\
(.081)\end{array}$ & \\
\hline GDP change & & $\begin{array}{c}-.565 \\
(.573)\end{array}$ & & $\begin{array}{l}-.319 \\
(.461)\end{array}$ \\
\hline CPI change & & $\begin{array}{c}-1.129^{* *} \\
(.469)\end{array}$ & & $\begin{array}{c}1.055^{* * *} \\
(.377)\end{array}$ \\
\hline election year T-1 & & $\begin{array}{c}.008 \\
(.0 .31)\end{array}$ & & $\begin{array}{l}-.046^{*} \\
(.025)\end{array}$ \\
\hline adjusted R-square & 0.1124 & 0.0883 & 0.1226 & 0.077 \\
\hline $\begin{array}{l}\text { number of } \\
\text { observations }\end{array}$ & 850 & 850 & 850 & 850 \\
\hline number of firms & 36 & 36 & 36 & 36 \\
\hline probability $>\mathrm{F}$ & 0.000 & 0.175 & 0.000 & 0.010 \\
\hline Firm fixes effects & yes & yes & Yes & Yes \\
\hline Year dummies & yes & no & Yes & No \\
\hline
\end{tabular}


List I

Definitions of Variables for Tables I-III

\begin{tabular}{|c|c|}
\hline Firm variables & \\
\hline Name of variable & Definition \\
\hline Income & Annual income \\
\hline EBITDA/income & $\begin{array}{l}\text { Earnings before interest, taxes, depreciation, and amortization divided by } \\
\text { annual income. }\end{array}$ \\
\hline EBITDA/income T-1 & The EBITDA/income ratio for the preceding year. \\
\hline ROE & Return on equity. i.e., net income divided by shareholders' equity. \\
\hline Dividend/ income & Annual dividends distributed divided by annual income. \\
\hline $\begin{array}{l}\text { Percent of firms paying } \\
\text { dividend }\end{array}$ & Percent of firms that paid dividend. \\
\hline Number of em ployees & Number of employees in firm. \\
\hline Board-m ember resigned & $\begin{array}{l}\text { A binary variable which equals } 1 \text { in cases in which the board-member did } \\
\text { not serve the full three-year term for which she was nominated. }\end{array}$ \\
\hline Board-member re-elected & $\begin{array}{l}\text { A binary variable which equals } 1 \text { in cases in which the board-member was } \\
\text { re-nominated at the end of her term. }\end{array}$ \\
\hline
\end{tabular}

continued on next page 
List I - continued

\begin{tabular}{|c|c|c|}
\hline $\begin{array}{l}\text { Name of } \\
\text { variable }\end{array}$ & Definition & Source \\
\hline GDP growth & $\begin{array}{l}\text { Annual GDP rate of growth (in constant prices). GDP is defined as } \\
\text { the sum of the gross value added of all resident producers at } \\
\text { producers' prices, plus taxes less subsidies on imports, plus all } \\
\text { nondeductible VAT (or similar taxes). }\end{array}$ & $\begin{array}{l}\text { Israel's Central } \\
\text { Bureau of Statistics }\end{array}$ \\
\hline CPI change & $\begin{array}{l}\text { Annual consum er price in dex change. Consumer price index is } \\
\text { measured as the percent change over time in the expenditure } \\
\text { necessary for purchasing a fixed "basket" of goods and services, } \\
\text { whose prices can be measured regularly. This "basket" represents } \\
\text { the consumption of the households. }\end{array}$ & $\begin{array}{l}\text { Israel's Central } \\
\text { Bureau of Statistics }\end{array}$ \\
\hline $\begin{array}{l}\text { Consumption } \\
\text { change }\end{array}$ & $\begin{array}{l}\text { Annual change in private consumption expenditure. Private } \\
\text { consumption expenditure is defined as consumption expenditure } \\
\text { of households and the consumption expenditure of non-profit } \\
\text { institutions serving hous eholds, where the major part of their } \\
\text { expenditure is not financed by the gov ernment. }\end{array}$ & $\begin{array}{l}\text { Israel's Central } \\
\text { Bureau of Statistics }\end{array}$ \\
\hline Wage change & $\begin{array}{l}\text { Annual change in av erage monthly wages per employee job. } \\
\text { Average monthly wages per employee job is defined as the gross } \\
\text { monthly wages divided by the number of employee jobs in that } \\
\text { month. }\end{array}$ & $\begin{array}{l}\text { Israel's Central } \\
\text { Bureau of Statistics }\end{array}$ \\
\hline $\begin{array}{l}\text { Election year } \\
\mathrm{T}-1\end{array}$ & $\begin{array}{l}\text { A dummy indicating whether the year examined was one year } \\
\text { following national elections. } 24\end{array}$ & $\begin{array}{l}\text { Homepage of the } \\
\text { Knesset - Israel's } \\
\text { parliament }\end{array}$ \\
\hline $\begin{array}{l}\text { Log income } \\
\text { T-1 }\end{array}$ & Log of annual income of the prec eding year. ${ }^{25}$ & $\begin{array}{l}\text { Calculated by author, } \\
\text { on the basis of data } \\
\text { published in the } \\
\text { GCA's annual reports } \\
\text { for GBCs, and on data } \\
\text { from the Super } \\
\text { Analyst system for } \\
\text { LCTs. }\end{array}$ \\
\hline
\end{tabular}

24 "Election year" was included in order to control for the political influence to which government com panies may be exposed, regarding the nomination of new board-members and the different regulation policies a new minister may impose, as well as the impact political changes may have on all firms in the economy. It was assumed that changes in government firms due to elections will occur in the year following the elections, allowing a reasonable period of time for the new ministers to make appointments of new board-members, replacing those whose term of service had ended. 


\section{Supplement B: Israeli Business Companies - Government versus Private}

In order to understand if, and in what respect, Israeli GBCs differ from private firms, GBCs are compared to the Israeli companies listed on the Tel-Aviv Stock Exchange (LCTs). The data pertaining to the GBCs were taken from the annual reports for 1997-2007 published by the GCA, which present key figures from the financial reports of all firms in which the Israeli government holds at least $50 \%$ of the shares. The data pertaining to the LCTs was taken from the Super Analyst (A-online) database, which compiles financial data regarding the Israeli listed companies. Table II presents the comparison.

As is evident from Table II, GBCs seem to have at least certain characteristics in common with LCTs: the average annual income of both types of firms equals several thousands of USD, although that of the GBCs is substantially larger (476 thousand USD for GBCs versus 265 thousand USD for LCTs), and both types of firms exhibit similar profitability margins ( $5.8 \%$ versus $6.9 \%$, respectively). In contrast, Table II also shows that, in comparison to LCTs, the likelihood that a GBC will distribute a dividend is very small. Moreover, when a dividend is paid by a GBC, it will be a significantly smaller percentage of the profit margin, as compared to that paid by an LCT.

In addition, the impact of macro-factors on GBCs versus LCTs is examined. This analysis is conducted to rule out the possibility that the GBCs examined are firms operating in their own "bubble", not affected by the outer business world although possibly affected by political factors, whereas, in contrast, listed firms operate in a dynamic environment in which changes in the economy, or in business conditions, easily impact firm performance.

Two separate sets of regressions were conducted: one set examines 39 GBCs (regressions 1-3 in Panels 1 and 2 of Table III) while the other examines the 712 LCTs 
(regressions 4-6 in Panels 1 and 2 of Table III). Both sets of regressions analyze panel data for the years 1997-2007. The dependent variables examined are EBITDA/income, ROE and Dividend/income ${ }^{26}$. The regressions control for the following macro-factors: GDP growth, CPI change, consumption change, wage change, election year T- 1 and log income T-1. All variables are defined in List I (presented at the end of Supplement A). Following the results of a Hausman test conducted (not presented), the regressions control for fixed effect across firms.

The results presented in Table III indicate that macro-factors impact upon the profitability of both GBCs and of LCTs: gross domestic growth is significantly negatively associated with the EBITDA/income ratio for both types of firms (Panel 1). The consumer price index is positively associated only with the EBITDA/income ratio of listed companies, while a change in consumption is positively associated only with the ROE of GBSc (Panel 2). Hence, these findings demonstrate that macro-factors impact upon the financial performance of both types of firms.

In contrast, regarding dividends, macro-factors affected differently each type of firm. The results in Table III demonstrate that nothing seemed to impact the GBCs' lack of tendency to distribute dividends. Yet, macro factors did impact upon the dividends paid by LCTs: LCTs paid significantly more dividends in years that witnessed high GDP growth rates and a decrease of average wages (which may have provided companies with higher profitability margins).

26 We examine dividend/income rather than dividend/investment, because data pertaining to the investments of GBCs was not av ailable. 
In order to assure robustness, several different sets of regression were conducted, which included only some of the macro-factors included in Table III and/or other macrofactors. By and large, the results presented in Table III are representative of the different versions conducted.

In sum, we may conclude that both GBCs and LCTs are impacted by macro factors. In contrast, the tendency of LCTs to pay dividends is significantly impacted by macro-factors, whereas that of GBCs seems to remain untouched by the world around them. 
Table II

Comparison of GBCs to Firms Listed on the Tel-Aviv Stock Exchange (LCTs)

This table presents a comparison between GBCs and LCTs. List I presents definitions for the variables pres ented in this table. All figures pertain to 2007.

\begin{tabular}{|c|c|c|c|c|c|c|}
\hline & \multicolumn{3}{|c|}{ GBCs } & \multicolumn{3}{|c|}{ LCTs } \\
\hline & Average & S.D. & $\begin{array}{c}\text { number of } \\
\text { observations }\end{array}$ & average & S.D. & $\begin{array}{c}\text { number of } \\
\text { observations }\end{array}$ \\
\hline income (in USD) & 476,952 & $1,076,846$ & 35 & 265,483 & 975,857 & 662 \\
\hline EBITDA/income 27 & $5.8 \%$ & 0.23 & 24 & $6.9 \%$ & 1.79 & 490 \\
\hline ROE & $10.6 \%$ & 0.11 & 29 & $9.7 \%$ & 0.99 & 518 \\
\hline dividend/net income & $0.94 \%$ & 0.041 & 35 & $7.26 \%$ & 0.388 & 661 \\
\hline perc ent of firms paying dividend & $14 \%$ & - & 35 & $44 \%$ & - & 662 \\
\hline number of employees & 1,531 & 3,178 & 31 & 624 & 1,717 & 478 \\
\hline
\end{tabular}

27 The figures presented for "EBITDA/income" and "ROE" exclude obs ervations with extreme values - those which, in absolute values, exceed the average by more than 3 S.D. 
Table III

\section{Macro Fact ors and Firm Performance}

Regressions 1-3 of Panels 1 and 2 analyze 39 business companies in which the Israeli government holds shares (GBCs), and Regressions 4-6 in both panels analyze 712 companies listed on the Tel-Aviv Stock Exchange (LCTs). All regressions examine panel data for the years 1997-2007, and control for fixed effects across firms. Definitions for the variables are presented in List I. For each variable presented, the first line presents the coefficients and the second line presents robust standard errors (in parentheses). ${ }^{* * *}, * *, *$, indicate significance at the $0.01,0.05$, and 0.10 lev el, respectively. Constant included but not pres ented.

As the results indicate, macro factors impact upon the profitability of both GBCs and LCTs. Concerning dividends, however, macro factors impact only upo n those distributed by LCTs.

Panel 1

\begin{tabular}{|c|c|c|c|c|c|}
\hline \multicolumn{3}{|c|}{ GBCs } & \multicolumn{3}{|c|}{ LCTs } \\
\hline (1) & (2) & (3) & (4) & (5) & (6) \\
\hline $\begin{array}{l}\text { EBITDA/ } \\
\text { income }\end{array}$ & ROE & $\begin{array}{l}\text { dividend/ } \\
\text { profit }\end{array}$ & $\begin{array}{l}\text { EBITDA/ } \\
\text { income }\end{array}$ & ROE & $\begin{array}{c}\text { dividend/ } \\
\text { profit }\end{array}$ \\
\hline$-24.51^{*}$ & 1.60 & 12.93 & $-9.59 *$ & -0.34 & $4.66^{* * *}$ \\
\hline (13.24) & (1.07) & $(9.96)$ & (5.53) & $(2.54)$ & (1.31) \\
\hline 6.39 & -0.49 & 11.10 & $9.75^{* *}$ & 0.76 & $-2.14^{* * *}$ \\
\hline (6.32) & (1.33) & (7.85) & (4.03) & $(1.45)$ & $(0.78)$ \\
\hline 0.56 & $-0.10^{*}$ & 0.04 & -0.63 & -0.01 & -0.02 \\
\hline$(0.51)$ & $(0.06)$ & $(0.35)$ & $(0.21)$ & $(0.12)$ & $(0.04)$ \\
\hline $13.68^{* * *}$ & 0.11 & .05 & $7.84^{* * *}$ & 0.02 & $-0.67 * * *$ \\
\hline (4.799) & $(0.12)$ & $(0.38)$ & (1.58) & $(0.14)$ & $(0.17)$ \\
\hline 0.536 & 0.218 & -0.025 & 0.281 & 0.051 & 0.15 \\
\hline 318 & 316 & 325 & 5158 & 5503 & 5521 \\
\hline 37 & 38 & 38 & 657 & 692 & 699 \\
\hline 0.057 & 0.025 & 0.478 & 0.000 & 0.981 & 0.003 \\
\hline
\end{tabular}

continued on next page 
Table III - continued

Panel 2

\begin{tabular}{|c|c|c|c|c|c|c|}
\hline & \multirow{2}{*}{\multicolumn{3}{|c|}{ GBCs }} & & & \\
\hline & & & & \multicolumn{3}{|c|}{ LCTs } \\
\hline & (1) & (2) & (3) & (4) & (5) & (6) \\
\hline & $\begin{array}{l}\text { EBITDA/ } \\
\text { income }\end{array}$ & ROE & $\begin{array}{l}\text { dividend/ } \\
\text { profit }\end{array}$ & $\begin{array}{l}\text { EBITDA/ } \\
\text { income }\end{array}$ & ROE & $\begin{array}{l}\text { dividend/ } \\
\text { profit }\end{array}$ \\
\hline \multirow[t]{2}{*}{ GDP change } & -17.816 & -1.25 & -15.292 & 8.92 & -1.31 & $3.31^{* *}$ \\
\hline & $(13.61)$ & $(1.49)$ & $(24.19)$ & $(9.71)$ & $(3.53)$ & $(1.32)$ \\
\hline \multirow[t]{2}{*}{ CPI change } & 6.49 & -0.78 & 0.31 & $16.96^{* * *}$ & -0.517 & -1.41 \\
\hline & $(8.44)$ & $(0.98)$ & $(8.71)$ & $(4.52)$ & $(2.35)$ & (1.08) \\
\hline \multirow[t]{2}{*}{ consumption change } & -1.24 & $3.38^{* *}$ & 12.06 & -9.98 & 1.704 & -0.41 \\
\hline & (12.69) & $(1.71)$ & $(22.67)$ & (10.88) & $(3.18)$ & $(1.31)$ \\
\hline \multirow[t]{3}{*}{ election year T-1 } & 0.42 & $-0.11^{* *}$ & -0.06 & -0.35 & -0.01 & 0.01 \\
\hline & $(0.51)$ & $(0.05)$ & $(1.79)$ & $(0.23)$ & $(0.14)$ & $(0.05)$ \\
\hline & $13.44^{* * *}$ & $.014^{*}$ & -0.38 & $7.78^{* * *}$ & 0.03 & $-0.65^{* * *}$ \\
\hline log income T-1 & $(4.68)$ & $(0.08)$ & $(0.285)$ & $(1.57)$ & $(0.14)$ & $(0.16)$ \\
\hline adjusted R-square & 0.533 & 0.229 & 0.093 & 0.282 & 0.051 & 0.15 \\
\hline number of observations & 318 & 316 & 325 & 5158 & 5503 & 5521 \\
\hline number of firms & 37 & 38 & 38 & 657 & 692 & 699 \\
\hline probability $>$ F & 0.075 & 0.024 & 0.56 & 0.000 & 0.998 & 0.003 \\
\hline
\end{tabular}




\section{Supplement C: Complete Coding Guidelines}

Minutes of board meetings and board-committee meetings of eleven GBCs were coded, as shall be described hereafter, for a period of one calendar year for each company. The year studied was between the years 2007and 2009 (in eight of the cases: 2008). Nine of the eleven companies examined provided minutes of both board meetings and boardcommittees; the other two supplied only the former. These data aggregate to 155 board meetings and 247 board-committee meetings, in which - according to our tabulation 2459 decisions were made or updates were given (1422 decisions and 1037 updates). The minutes of meetings total 4,758 pages. The average number of pages of minutes per board meeting is 14.2 ; for board-committee meetings it is 10.5 .

Due to confidentiality commitments made to the firms, which kindly provided copies of their minutes, we do not mention which specific firms were examined. However, we may state that all firms examined are included in Table 1, that they are of different sizes, as measured by annual income, with a tendency toward the larger GBCs; that they reflect quite representatively the fields in which Israeli government firms operate; and that of the

eleven firms examined, nine were completely, or virtually completely, owned by the Israeli government, the other two only partially (less than $50 \%$ of the shares were held by the government).

An important point which must be noted is that we do not analyze what occurs between the CEO and the board-members outside the boardroom. Undoubtedly, important occurrences take place outside the boardroom, but unless they are mentioned in the minutes, it is not possible to be aware of them. Nevertheless, although there are discussions 
and interactions outside the boardroom, the bulk of board-activity - including the decisionmaking process - takes place in the boardroom, so the analysis that shall be presented is valuable. In addition, we do not judge whether the actions taken by boards were positive or negative.

The data was coded according to the content-analysis methodology (Krippendorff, 2004; Lieblich et al., 1998), which allows the transformation of qualitative data into quantitative figures. The following principles were applied in coding the data:

xi. General information. For each issue discussed, the coding included the name of the company, date of meeting, number of pages of minutes, type of meeting (board/committee), and whether the issue was merely presented as an update or, alternatively, culminated in a decision made by the board. Board committees were further categorized as either: finance, human resource, audit, operational, regulation or contracting committee. In certain cases, a company had two or more different committees categorized under the same board-committee category.

xii. Topic-subjects. Each topic discussed or decision made in a board or board-committee meeting, was coded under one of the following twenty-three topic-subjects:

i. Appointing/firing an executive - executives include the CEO, his deputies, and the auditor.

ii. Appointment of members - to board-committees or boards of subsidiary firms.

iii. Approving minutes of past meetings - formal approval of the minutes by the board. 
iv. Audit - audit reports and audit issues regarding the firm.

v. Budget - updates, suggested changes, and projected budget are included under this category.

vi. Business issue - a standard business issue. For instance, in the case of a bank, waiving part of a problematic debt would be coded under this category.

vii. Business project - data regarding a specific project the firm or a subsidiary had undertaken or considered to undertake.

viii. Choosing a chairman for the meeting - companies which do not have a permanent chairman, elect a chairman for each board meeting.

ix. Contracting/purchases - contracts regarding purchasing raw materials, supplies, real estate, or services, including those of advisors and external accountants. This category includes problems that may arise within contractual relationships.

x. Cross-firm issues - an issue with across-the-firm implications (for example: proposed changes in the customer service, or moving the offices to a new location), or the plans of a specific unit that have ramifications and implications for the firm at large.

xi. Financial reports - discussions regarding the financial reports and the assumptions upon which they rely. 
xii. Formal issues - issues that must receive the formal approval of the board, such as granting the authority to sign a contract or financial reports, or to represent the firm in a general meeting.

xiii. Investment/finance - issues regarding money invested, borrowed from banks or the government, or raised from institutional investors or the stock market, and also issues regarding the firm's floating stock.

xiv. Legal - legal issues, including insurance.

xv. Ongoing general issues - ongoing continuing issues in the life of the firm, including brief anecdotal updates on issues previously discussed by the board. Note that most board meetings commenced with such brief updates presented by the CEO/chairman. When, however, distinct issues were discussed in detail, each was coded separately.

xvi. Organizational change - structural changes in the firm.

xvii. Personnel and compensation - employee benefits (e.g., receiving bonuses or leasing cars), behavioral problems among employees, changes in the total number of employees, general policies regarding employees, and a limited range of issues regarding compensation and benefits received by the boardmembers.

xviii. Ratification of audit committee - In cases in which an issue discussed previously by a board committee was discussed again by the board, the discussion on the board was coded under the relevant topic-subject. In cases 
in which the decision made by the board committee was only briefly presented, so as to allow the board to ratify the decision, the decision was coded under the relevant ratification topic-subject. "Ratification of audit committee" refers to ratification of decisions made by the audit boardcommittee.

xix. Ratification of financial committee - according to the rationale presented in paragraph xviii, this pertains to ratifications of decisions made by the financial board-committee.

xx. Ratification of human resources committee - according to the rationale presented in paragraph xviii, this pertains to ratifications of decisions made by the human resources board-committee.

xxi. Ratification of operational committee - according to the rationale presented in paragraph xviii, this pertains to ratifications of decisions made by the operational board-committee.

xxii. Regulation and government - all aspects regarding the relationship with the government, whether as regulator, shareholder, or otherwise. Examples of issues included are fees determined by the regulator, dividends requested by the government, and privatization.

xxiii. Strategic issues - discussion regarding the strategic business plan of the firm, or at least of a major activity of the firm, for the following years. 
xiii. Aggregate topic-subjects. In order to allow a simple and meaningful analysis, the 23 topic-subjects described above were divided into five aggregate topic-subjects as follows:

i. Audit and contracting - includes the topic-subjects: audit, contracting/purchases, legal, and ratification of audit committee.

ii. Business issues - includes the topic-subjects: business issues, business projects, cross-firm issues, ongoing general issues, ratification of operational committee, regulation and government, and strategic issues.

iii. Financial issues - includes the topic-subjects: budget, financial reports, investment/finance, and ratification of financial committee.

iv. Formal issues - includes the topic-subjects: appointments of members, approving past minutes of meetings, choosing a chairman for the meeting, and formal issues.

v. Personnel and benefits - includes the topic-subjects: appointing/firing an executive, organizational change, personnel and benefits, and ratification of human resources committee.

xiv. Decision in line with CEO. For each decision made by the board, the decision was coded as either in line, partially in line, or not in line with the CEO's/management's 
proposal. ${ }^{28}$ In cases in which the CEO's/management's view was not presented, its view was coded as "neutral."

xv. Further updates. Cases in which the board requested to receive further information or an update on the subject discussed. In cases in which concerning a single topic discussed, more than one update or further information was requested it was, nevertheless, coded as one request.

xvi. Taking an initiative. When a board actively did something that was meant to improve the company, according to its own understanding, this was coded as either a "minor initiative" or as a "major initiative."

"Minor initiative" indicates that the board slightly modified the original proposal. The following three examples illustrate which cases were coded under this category: (i) The board approved a lease it was asked to approve, yet decided to introduce a few revisions of details; (ii) The board requested that some moderate action be taken, for instance, that the CEO write a letter to the regulator about an issue discussed at the board meeting; (iii) The board decided to form a committee to handle a certain issue, or to appoint someone to take care of it, but at the point of time this

\footnotetext{
${ }^{28}$ In cas es in which the chai rman received a monthly salary, and accordingly dedicated most of his time to the firm, it is generally evident from the minutes that, in the boardroom, his views were fully coordinated and aligned with thos e of the CEO. In these cases, the chairman usually complemented the CEO and vice versa. Accordingly, views of chairmen who receive monthly salari es were regarded and coded as identical to those of the CEO. In contrast, in firms in which the chairman was only compensated on a base of board/committee meetings he attended, his views were not always coordinated and aligned with those of the CEO, and therefore, he was regarded as a board member, and his views were coded accor dingly as views of the board.
} 
decision was made it is, of course, impossible to know whether the committee or the individual appointed actually took any action. ${ }^{29}$

The second code, "major initiative", indicates that the board took an active part in defining the steps/actions that should be taken. The following two examples illustrate which cases were coded under this category: (i) A board delved into an issue presented to it, or into an issue it actively asked to discuss. For instance, if a board requested to examine the company's policy concerning perks (including, for example, which employees were eligible to be driven to work, at what times and under what circumstances), then discussed the policy concerning that perk quite thoroughly, and finally, formulated and adopted a new alternative policy, that would be coded as "major initiative"; (ii) A board actively sought, both within the boardroom and elsewhere, to change the regulation imposed on the firm. ${ }^{30}$

xvii. Interregnum. Cases in which the firm had no CEO at the time the board or boardcommittee meeting was held.

xviii. Presentation of alternatives. Cases in which the board was presented with at least two alternatives, including cases in which the CEO/management made its own preference clear.

xix. Dissension. Cases in which a decision was made, and one or more of the boardmembers did not vote as the others (either opposing them or abstaining).

\footnotetext{
29 If the minutes of subsequent meetings documented that they did take a major initiative, it was categorized accordingly for that subsequent meeting.

30 One may argue that this specific coding category is one with a "soft" defi nition. Accordingly, great care was taken to assure that the coding be conducted according to consistent standards: after the coding was completed, apart from the general rechecking of all of the coding, the coding of this specific category was carefully re-examined throughout all minutes examined.
} 
xx. Supervision. All topic-subjects were divided according to whether they were of supervisory nature or not. Supervisory topic-subjects were defined as: appointment of members, approving minutes of earlier meetings, audit, choosing a chairman for the meeting, contracting/purchases, financial reports, formal issues, legal, personnel and benefits, ratification of audit committee, ratification of human resources committee, ratification of operational committee, ratification of financial committee, and regulation and government. ${ }^{31}$ Non-supervisory topic-subjects were defined as: appointing/firing an executive, budget, business issue, business project, cross-firm issues, investment/finance, ongoing general issues, organizational change, and strategic issues.

xxi. Size of board and board composition. For each meeting, the total number of attending board-members was coded, along with the number of attending women directors, minority (Arabs) directors, and inside directors. ${ }^{32}$

xxii. Consistency. All coding was done by the authors - Miriam Schwartz-Ziv. ${ }^{33}$ To assure consistent standards, she reviewed all coding at least twice.

\section{Supplement D: Qualitative Examples}

This appendix presents brief case-studies of situations encountered when reading the minutes. In some of the cases we compare how similar situations developed differently in two different board-rooms. This appendix has two goals: first, to demonstrates the findings in a tangible way, adding a dimension which figures cannot convey; and secondly, to

\footnotetext{
31 For example, if a board approved a financial report, it was classified under the category of supervision because the board's role with regard to these reports is mainly verifying that they are properly conducted.

32 As mentioned, inside directors were defined as government employees and firm employees. The GCA board-representative was considered a government employee.

33 This was due to the fact that the minutes are in Hebrew and, due to confidentiality, were made available only to the authors.
} 
demonstrate that the situations faced by the boards examined could easily be encountered by other boards as well, regardless of whether a government is a major shareholder of the firm.

\section{a. The Board as a Supervisor (Relates to Section 4.1.1)}

In two large firms the board was requested to approve an early retirement plan pertaining to a substantial number of employees. The plan entailed heavy costs for both firms. In the first firm, the CEO reminded the board that it had discussed the issue two years earlier and, at that time, had approved the early retirement of a large number of employees. He explained that the current request was with in the framework of what had been discussed and approved by the board at that time.

Although it is reasonable to assume that most board-members had changed since the discussion the CEO was referring to had taken place, the board did not seem to be concerned with the time lag. One board-member asked a question: What are the costs of hiring new employees compared to the alternative - continuing to employ the people the CEO wanted to take early retirement? The answer she received was: The new employees will cost less than the current ones. The board was provided with one figure which, according to the CEO, summarized the costs entailed by the plan he had proposed. He did not explain what assumptions were made when calculating this figure, and which costs were included and which were left out; thus, for example, he did not clarify whether the figure he provided included lump-sum payments to employees who retired early. Nonetheless, this information was sufficient for the board to approve the CEO's request, rather immediately. 
In the second firm, in which the CEO also requested that the board approve a similar request, the board-members asked the same question: What costs does the early retirement program entail? The CEO had expected to hear this question, and immediately provided the board with detailed figures regarding the different costs associated with the program, including both direct and indirect costs. Nevertheless, the board wanted to receive additional information, regarding the specific criteria which would be used to determine which employees would be entitled to retire early, and from which specific professions the company was planning to hire new employees in place of those that would retire. Only after the board received this information (and more) at the following meeting, and discussed the information provided to it, did it approve the CEO's request.

This example demonstrates that there is no fixed script for how situations develop in the boardroom. In similar situations, one board can rather immediately approve the CEO's proposal, while another will want to delve into the issue, which may include requesting further information, before making a decision.

\section{b. The Involvement of Boards in the Actual Business (Relates to Section 4.1.2)}

There is probably an almost unlimited number of examples, from each of the boards examined, which demonstrate how boards made a decision, after discussing at length and considering thoroughly all options, regarding relatively marginal issues. For example, discussions on the compensation an executive departing the firm should receive tended to be long and emotional despite the fact that the maximum sum these boards are allowed to approve is no more than fifty thousand USD. Naturally, these discussions concluded with a decision made by the board. 
In contrast, when it came to the actual business of the firm (coded in this study under the aggregate topic-subject "business issues"), the involvement and energy invested by the same board-members in the discussion, was in many cases much more moderate than that described in the preceding case, although the sums involved were often much more substantial. The following two examples will illustrate this.

The first example pertains to the CEO's regular practice of providing the board with updates on business issues at the beginning of each board meeting. In certain cases these updates concern issues which can almost be regarded as strategic ones - but nevertheless the board's involvement is often minimal. For example, one of the companies examined had a chain of stores. The CEO of this company regularly updated the board as to which stores the firm was planning to open and close, and why and how these changes were planned to be implemented. This information was delivered to the board as an update, and the board was not even requested to formally approve these planned changes.

A second example demonstrating how boards were not offered (and did not demand) the opportunity to make a decision regarding the actual business is from a firm that operated with strategic partners abroad, whose specific location and identity greatly impacted the firm. The firm encountered a situation in which it was forced to stop working with one of its major strategic partners, and was compelled to find a new strategic partner. The CEO of this firm regularly updated the board on the different strategic partners he was negotiating with.

When the time came to choose the new strategic partner, the CEO made the decision. He explained to the board why he chose to collaborate with the chosen strategic partner, i.e., his decision was delivered to the board as an update, and was not even 
formally approved by the board. The only decision the board was requested to make in this case was to approve the relevant legal papers, which were presented to the board two meetings after the CEO announced his decision.

\section{c. Presentation of Alternatives (Relates to Section 4.1.2.1)}

Although the minutes examined document requests of board-members that they be presented with alternatives, the same board-members making these requests wanted the alternatives to be presented with a clear recommendation as to which alternative the CEO/management preferred. The following example, of a rare and almost unique case in which boards were requested to choose between two alternatives, demonstrates this point.

The case concerned specific assumptions that had to be made in the firm's financial reports. These assumptions impacted the financial reports dramatically. Different parties involved (internal and external to the firm) disagreed upon these assumptions and, consequently, the board was requested to approve one of two different sets of assumptions presented to them. The members of the board refused to make a decision, instead demanding that the parties involved agree upon one set of assumptions - which would thereafter be presented to the board for approval.

In this case, only after this dispute continued for several months, and the board was left with no choice but to take a stand, did it eventually take one.

d. Disagreement Between the Board and the CEO (Relates to Section 4.2.1) 
When a board disagreed or opposed the CEO's suggestions, something of a power struggle occurred in the boardroom. This power struggle could develop quite differently in different boardrooms. For example, in two different boardrooms the CEO requested that the board approve the annual budget he proposed. In both cases the board was of the opinion that the budget should be cut substantially. However, these situations developed quite differently in the two board-rooms.

In the first firm, the board demanded that the CEO put together a different budget in which large cuts be made, some of which were specifically discussed in the boardroom. The process of re-examining and updating the budget evolved in the course of several board meetings, and affected directly major financing decisions. In sum, in this case the board did not vote in line with the CEO's proposal.

In contrast, in the second firm, the CEO responded to the demand that he cut the proposed budget by stating that he viewed the board's intervention in the annual budget as verging upon a vote of no confidence in him. He reminded the board-members that in the previous year too, the board had approved a budget with a deficit, and he stated explicitly that if the board believed in him as a CEO, and wished that he continue serving in this role, the proposed budget was the only one with which he could work. This tactic did indeed work for this CEO, and after several rounds of posturing and negotiations, which all occurred in one meeting, the board approved the budget proposed by the CEO. In this case, the CEO "won".

e. Initiatory Boards (Relates to Section 4.2.3) 
The minutes examined document several cases in which board-members explicitly stated that they are not willing to serve as mere rubber-stamps. There is, however, quite a distance between not serving as a rubber stamp, on the one hand, and taking action, on the other. Nevertheless, the latter does at times occur: in many cases board-members attempted to make an active contribution in specific fields and niches in which they had prior knowledge and expertise, as the following example demonstrates.

In several of the firms examined, which provided a substantial number of cars to their employees, the board was requested to approve the firm's policy as to which employees were eligible. Most boards that discussed this issue went through a standard ritual: the board asked several questions, a discussion was held, and the CEO's proposal was approved.

However, in one firm, a specific board-member had expertise in this field. He encouraged the board to thoroughly examine this issue: during two meetings, the board examined carefully who was entitled to receive a vehicle, which type of vehicle employees of different rank were entitled to receive, and how the firm's policy compared to that of other companies and to that of the government. Following this examination, the board formulated and approved a new policy on this issue, which was implemented by the firm. In this case, the decision made by the board was coded as one by which the board took a major initiative. 